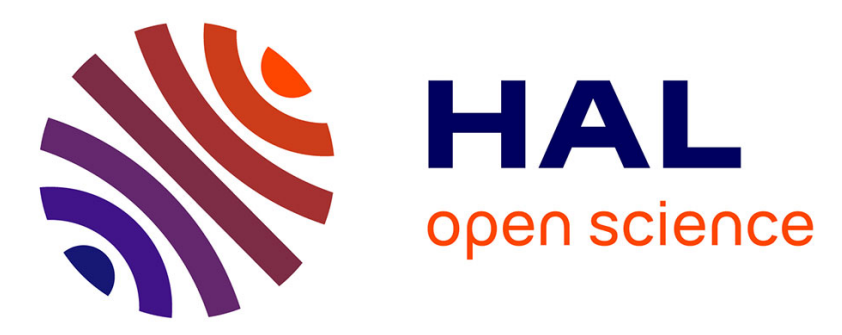

\title{
DNA junction ligands trigger DNA damage and are synthetic lethal with DNA repair inhibitors in cancer cells
}

Katerina Duskova, Pauline Lejault, Élie Benchimol, Régis Guillot, Sébastien Britton, Anton Granzhan, David Monchaud

\section{To cite this version:}

Katerina Duskova, Pauline Lejault, Élie Benchimol, Régis Guillot, Sébastien Britton, et al.. DNA junction ligands trigger DNA damage and are synthetic lethal with DNA repair inhibitors in cancer cells. Journal of the American Chemical Society, 2019, 10.1021/jacs.9b11150 . hal-02412757

\section{HAL Id: hal-02412757 \\ https://hal.science/hal-02412757}

Submitted on 15 Dec 2019

HAL is a multi-disciplinary open access archive for the deposit and dissemination of scientific research documents, whether they are published or not. The documents may come from teaching and research institutions in France or abroad, or from public or private research centers.
L'archive ouverte pluridisciplinaire HAL, est destinée au dépôt et à la diffusion de documents scientifiques de niveau recherche, publiés ou non, émanant des établissements d'enseignement et de recherche français ou étrangers, des laboratoires publics ou privés. 


\title{
DNA junction ligands trigger DNA damage and are synthetic lethal with DNA repair inhibitors in cancer cells
}

\author{
Katerina Duskova, ${ }^{1}$ Pauline Lejault, ${ }^{1}$ Élie Benchimol, ${ }^{2,3}$ Régis Guillot, ${ }^{4}$ \\ Sébastien Britton, ${ }^{5, \star}$ Anton Granzhan ${ }^{2,3, \star}$ and David Monchaud ${ }^{1, \star}$
}

\begin{abstract}
${ }^{1}$ Institut de Chimie Moléculaire de l'Université de Bourgogne (ICMUB), CNRS UMR 6302, UBFC Dijon, 21078
Dijon, France; “david.monchaud@cnrs.fr. ${ }^{\star}$ Institut Curie, CNRS UMR 9187, INSERM U1196, PSL Research University, 91405 Orsay, France. ${ }^{3}$ Université Paris-Sud, Université Paris Saclay, CNRS UMR 9187, INSERM

U1196, 91405 Orsay, France; *anton.granzhan@curie.fr. ${ }^{4}$ Institut de Chimie Moléculaire et des Matériaux d'Orsay (ICMMO), CNRS UMR 8182, Université Paris-Sud, Université Paris Saclay, 91405 Orsay, France. ${ }^{5}$ Institut de Pharmacologie et de Biologie Structurale (IPBS), CNRS UMR 5089, Université de Toulouse, UPS, Equipe labellisée la Ligue Contre le Cancer, 31077 Toulouse, France; `sebastien.britton@ipbs.fr
\end{abstract}

Abstract. Translocation of DNA and RNA polymerases along their duplex substrates results in DNA supercoiling. This torsional stress promotes the formation of plectonemic structures, including three-way DNA junction (TWJ), which can block DNA transactions and lead to DNA damage. While cells have evolved multiple mechanisms to prevent the accumulation of such structures, stabilizing TWJ through ad hoc ligands offer an opportunity to trigger DNA damage in cells with high level of transcription and replication, such as cancer cells. Here, we develop a series of azacryptand-based TWJ ligands, we thoroughly characterize their TWJ-interacting properties in vitro and demonstrate their capacity to trigger DNA damage in rapidly dividing human cancer cells. We also demonstrate that TWJ ligands are amenable to chemically induced synthetic lethality strategies upon association with inhibitors of DNA repair, thus paving the way towards innovative drug combinations to fight cancers.

\section{Introduction}

Non-canonical secondary DNA structures encompass all DNA architectures that deviate from the canonical B-DNA with Watson-Crick double helix. The topological diversity of the non-canonical structures comprises other two-stranded forms (e.g., Z-DNA), ${ }^{1-3}$ as well as three-stranded (e.g., three-way DNA junction, ${ }^{4-6}$ triplex, $^{7-8}$ R-loops), ${ }^{9-11}$ and four-stranded architectures (e.g., four-way, or Holliday DNA junction, ${ }^{6,12-13}$ quadruplex, ${ }^{14-15}$ i-motif). ${ }^{16-17}$ The 
demonstration of the existence of these structures in cells, along with the precise assessment of their functional roles, stems from the massive efforts of the chemical biology community. For instance, immunodetection approaches have been successfully implemented to visualize quadruplexes ${ }^{18}$ and i-motifs ${ }^{19}$ in human cells only recently. Also, many chemical programs have been necessary to develop quadruplex ligands ${ }^{20-21}$ and i-motif ligands $s^{22-23}$ to perturb intracellular equilibria in order to gain insights into the processes they are involved in. Collectively, recent investigations have demonstrated that a common aftermath of targeting unusual DNA structures in human cells with small molecules is the induction of DNA damage. ${ }^{24-26}$ While the exact mechanism by which the ligands trigger DNA breakage is still unclear (and may be multifactorial), an admitted hypothesis is that non-canonical structures act as impediments to DNA transactions (replication and transcription). ${ }^{25-29}$ These structures indeed represent physical roadblocks to polymerase translocation along the genomic DNA, ${ }^{30}$ and their stabilization by external chemicals triggers protein machinery stalling or collapses that eventually lead to DNA breakage. This has been documented by studies performed with the quadruplex stabilizers telomestatin, ${ }^{31-32}$ RHPS4, ${ }^{33-34} 360 \mathrm{~A},{ }^{35}$ pyridostatin (PDS) ${ }^{36-37}$ (which also exerts its effect in a R-loop-dependent manner) ${ }^{38}$ and CX-5461 39 for instance, but far less with other unusual DNA structure targets. ${ }^{40}$

Here, we focus on three-way DNA junctions (TWJ, Figure 1) and demonstrate that the targeting of TWJ structures in human cells by designed ligands actually triggers DNA damage that could yield real therapeutic dividends. Thanks to the high-throughput screening assay TWJ-screen, ${ }^{41}$ we recently investigated $>1200$ chemicals to identify promising TWJ-ligands and spotted the azacryptand 3,3'-TrisBP (reported as compound 471 in ${ }^{42}$, Figure 1), which displays enticing in vitro TWJ-interacting properties. This compound indeed promotes TWJ assembly from separated strands (TWJ-screen and gel electrophoresis), displays a high TWJ-affinity ( $K=$ $3.9 \times 10^{6} \mathrm{M}^{-1}$ by ESI-MS and $K=6.0 \times 10^{6} \mathrm{M}^{-1}$ by equilibrium dialysis) and, above all, an exquisite selectivity for TWJ over duplex-DNA (competitive FRET-melting assay, comparative ESI-MS and equilibrium dialysis). ${ }^{42-43}$ These excellent properties are likely to originate in its prismatic molecular shape, which makes it suited to fit snugly within the privileged binding site of TWJ, the junction point of TWJ (or central cavity, schematically represented in Figure 1). ${ }^{44-45}$ This ligand was also found quite toxic for breast cancer cells $\left(I C_{50}=1.30 \mu \mathrm{M}\right.$ for both the hormone-responsive MCF-7 and the triple-negative MDA-MB-231 lines upon 72-h treatment), with a less pronounced effect on non-malignant cells $\left(I C_{50}=2.60 \mu \mathrm{M}\right.$ for $\mathrm{BJ}$ - 
hTERT). We thus decided to further exploit the azacryptand chemical scaffold in the hope of identifying TWJ-ligands with improved properties to further characterize the origins of their cellular effects. We demonstrate here, via the study of the three new derivatives, that the azacryptands are indeed valuable molecular tools to trigger DNA damage in treated cancer cells and that their anticancer properties can be further potentiated by inhibitors of DNA reparation in a chemically induced synthetic lethality approach. ${ }^{46-48}$

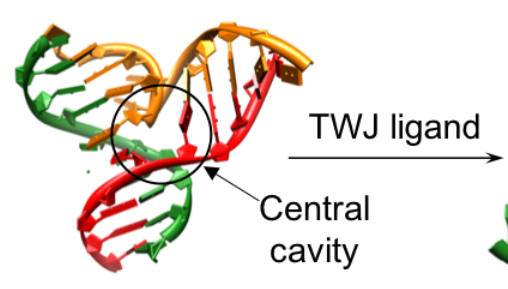

Three-way DNA junction

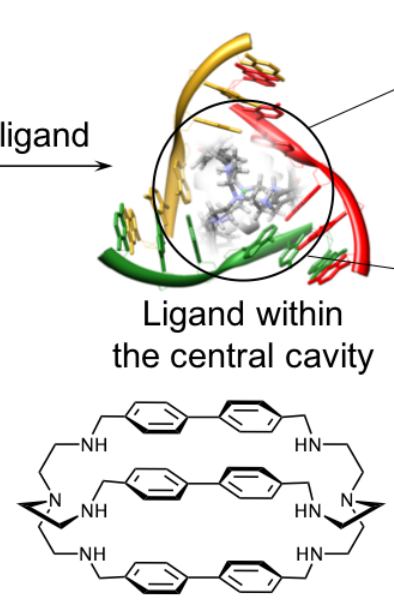

4,4'-TrisBP
3,'-TrisBP

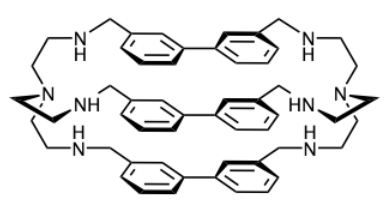

3,3 -TrisBP

Figure 1. Upper panel, left: schematic representation of a three-way DNA junction (TWJ), alone or interacting with a ligand bound within the central cavity; right: solid-state structure of TrisPOB $\times 6 \mathrm{HCl}$, obtained from singlecrystal X-ray diffraction analysis (CPK colors). Lower panel: chemical structures of studied compounds.

\section{Results.}

Design and synthesis of 3,3'-TrisBP analogues. Three novel azacryptands $\left(4,4^{\prime}\right.$-TrisBP, ${ }^{49}$ TrisPOB and TrisPSB, Figure 1) were prepared through the [3 + 2]-type condensation of tris(2aminoethyl)amine (or tren) and the corresponding aromatic dialdehydes, followed by the $\mathrm{NaBH}_{4}$ reduction of hexaimine intermediates according to established procedures (Scheme S1). ${ }^{43,} 50$ Of note, at physiological $\mathrm{pH}$, azacryptands are expected to exist as a mixture of predominantly tri- and tetra-protonated species, as demonstrated with related systems. ${ }^{51-52}$ In the case of TrisPOB, structural details were established by single-crystal X-ray crystallography of the corresponding hydrochloride salt (Figure 1; Figure S1 and Table S1). The solid-state molecular structure showed an extended capsular shape with a length of $c a .14 .7$ $\AA$ (distance between the tertiary $\mathrm{N}$ atoms). The two chloride ions were found tightly bound via hydrogen bonds to three protonated secondary amino groups, and a symmetry-distorted 
solvent molecule ( $\mathrm{MeOH}$, not shown) inside the azacryptand cavity. This demonstrated the enhanced flexibility and capacity to accommodate guests, as compared to a recently reported hexaimine analogue described by Lehn and coworkers. ${ }^{50}$ The pseudo- $C_{3}$-symmetrical, prismatic shape of TrisPOB thus appeared perfectly suited to interact with TWJ (schematically represented in Figure 1), justifying the choice of the azacryptand molecular scaffold.

A

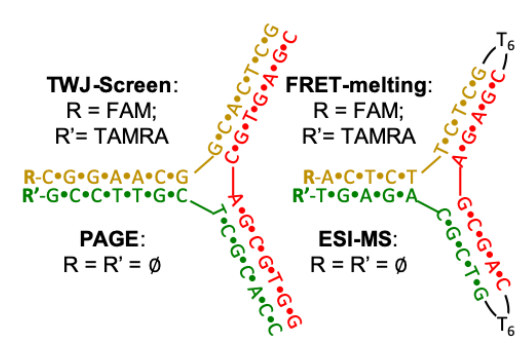

C

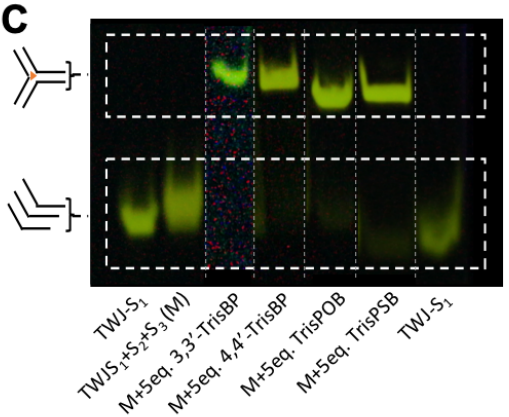

E

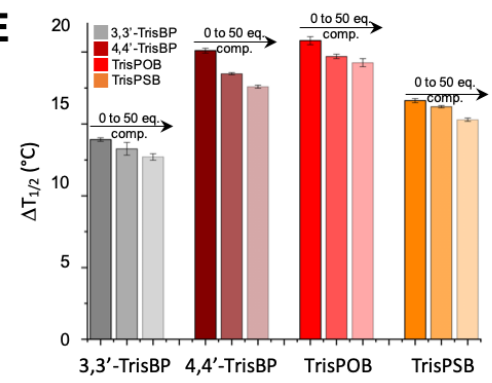

B

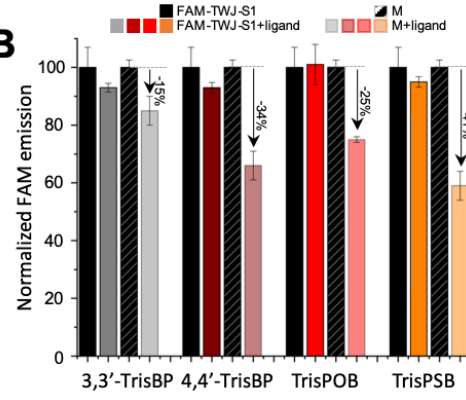

D

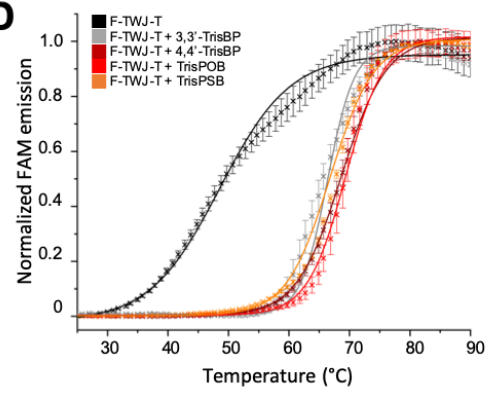

$\mathbf{F}$

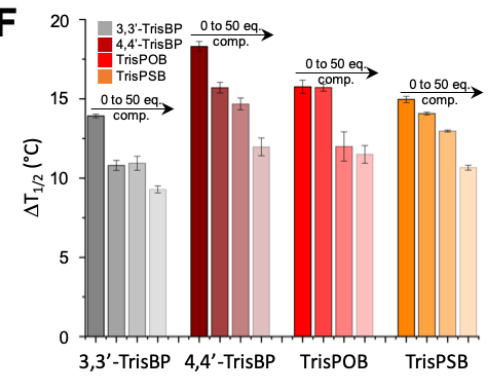

G
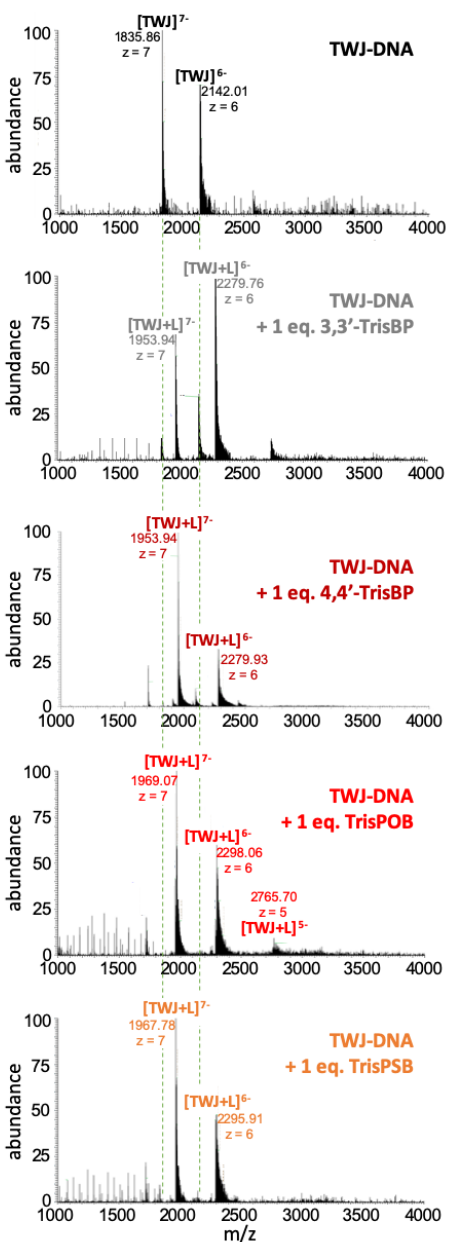

Figure 2. A. Schematic representation of the TWJ-forming oligonucleotides used in this study. B. TWJ-Screen results of experiments performed FAM-TWJ- $\mathrm{S}_{1}$, TWJ-S$_{2}$ and TWJ-S $\mathrm{S}_{3}$-TAMRA $(0.2 \mu \mathrm{M})$ in presence of 3,3'-TrisBP, 4, $4^{\prime}-$ TrisBP, TrisPOB and TrisPSB $\left(1 \mu \mathrm{M}, 37^{\circ} \mathrm{C}, 1 \mathrm{~h}\right)$. C. Native PAGE performed with TWJ-S $\mathrm{S}_{1}, \mathrm{TWJ}_{-} \mathrm{S}_{2}$ and TWJ-S 3 $(5.0 \mu \mathrm{M})$ in presence of $3,3^{\prime}-$ TrisBP, $4,4^{\prime}-$ TrisBP, TrisPOB and TrisPSB $\left(25.0 \mu \mathrm{M}, 4^{\circ} \mathrm{C}, 1 \mathrm{~h}\right.$; gels post-stained with SybrGold; multiple gels assembled in a single image). D. FRET-melting curves (dots: experimental data; line: fitted curves) of experiments performed from 25 to $90^{\circ} \mathrm{C}$ with F-TWJ-T (0.2 $\left.\mu \mathrm{M}\right)$ in presence of 3,3'-TrisBP, 4,4'-TrisBP, TrisPOB and TrisPSB $(1.0 \mu \mathrm{M})$. E,F. Results of competitive FRET-melting experiments performed with F-TWJ-T $(0.2$ $\mu \mathrm{M})$ in presence of $3,3^{\prime}-$ TrisBP, 4,4'-TrisBP, TrisPOB and TrisPSB $(1.0 \mu \mathrm{M})$ and increasing concentrations of the duplex ds26 $(\mathrm{E}, 0,3.0$ and $10.0 \mu \mathrm{M})$ or the quadruplex $\mathrm{TG}_{4} \mathrm{~T}(\mathrm{~F}, 0,1.0,2.0$ and $10.0 \mu \mathrm{M})$. G. ESI-MS of TWJ alone (upper panel) or of the association between TWJ $(10.0 \mu \mathrm{M})$ and 3,3'-TrisBP, 4,4'-TrisBP, TrisPOB and TrisPSB (10.0 $\left.\mu \mathrm{M}, 1 \mathrm{~h}, 25^{\circ} \mathrm{C}\right)$.

Quantification of the TWJ-interacting properties in vitro. The TWJ-interacting properties of these three novel derivatives were assessed via a panel of in vitro techniques (Figure 2) and 
compared to the parent compound 3,3'-TrisBP. We first investigated their ability to assemble TWJ from three separated strands (Figure 2A) via the TWJ-screen assay:41-42 a mixture (M) of

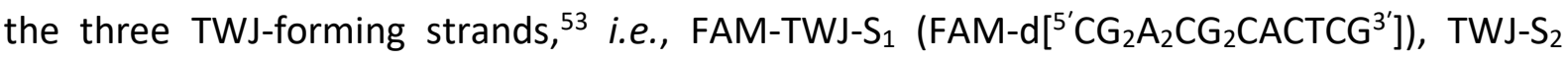

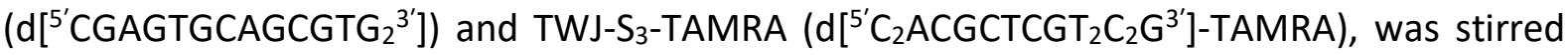
at $37{ }^{\circ} \mathrm{C}$ for $1 \mathrm{~h}$ without (control, along with FAM-TWJ-S alone to define the $100 \%$ FAM emission) or with 5 molar equivalents (mol. equiv., $1.0 \mu \mathrm{M}$ ) of the four compounds. The efficiency of the ligands to shift the equilibrium towards the folded TWJ is quantified by comparing the normalized fluorescence intensity (NFI) of FAM-TWJ-S ${ }_{1}$ alone (defined as $100 \%$ ) with that of [FAM-TWJ-S $1+$ ligand] to discard unwarranted compounds interaction with the $\mathrm{S}_{1}$ strand, and the NFI of the mixture $\mathrm{M}$ with that of [M + ligand] to quantify the TWJ folding per se. Collected results (Figure $2 \mathrm{~B}$ ) indicate that the azacryptands marginally interact with the FAM label ( $\mathrm{NFI}_{\text {FAM-TWJ-S1+ligand }}$ between +1 and $-7 \%$ as compared to $\mathrm{NFI}_{\text {FAM-TWJ-S1 }}$ ) and that the three new derivatives trigger TWJ-folding more efficiently than 3,3'-TrisBP $\left(\mathrm{NF} \mathrm{I}_{\mathrm{M}-[\mathrm{M}+\mathrm{ligand}]}=-\right.$ 34, -25 and $-41 \%$ as compared to $\mathrm{NFI}_{\mathrm{M}}$ for $4,4^{\prime}-$ TrisBP, TrisPOB and TrisPSB, respectively, versus $-15 \%$ for $3,3^{\prime}$-TrisBP).

These results were confirmed by native polyacrylamide gel electrophoresis (PAGE), performed with the same sequences without fluorescent label (Figure 2A). ${ }^{41,43}$ The three separated strands TWJ-S 1, TWJ-S 2 and TWJ-S 3 were stirred at $25^{\circ} \mathrm{C}$ for $1 \mathrm{~h}$ without (control) or with 5 mol. equiv. of the four compounds. Gels (15\% polyacrylamide, $5.0 \mu \mathrm{M}$ DNA loading/well) were run for $1 \mathrm{~h}$ prior to be stained (SYBR Gold). Results seen in Figure 2C allowed for a straightforward, yet qualitative, visualization of the TWJ folding ability of the candidates, monitored by the difference of migration between controls (both TWJ-S $\mathrm{S}_{1}$ alone and the mixture $\mathrm{M}$ ) and the folded TWJ/ligand complexes, which migrate significantly more slowly, due to their shapes and charges.

Next, we studied the interaction of ligands with pre-folded TWJ via the fluorescence resonance energy transfer (FRET)-melting assay (Figure 2D). ${ }^{42,}{ }^{54-55}$ To this end, the intramolecular, doubly labeled FAM-d $\left[{ }^{5^{\prime}} \mathrm{A}(\mathrm{CT})_{2}(\mathrm{TC})_{2} \mathrm{G}-\mathrm{T}_{6}-\mathrm{C}(\mathrm{GA})_{2} \mathrm{GCGAC}-\mathrm{T}_{6}-\mathrm{GTCGC}(\mathrm{AG})_{2} \mathrm{~T}^{3^{\prime}}\right]-$ TAMRA system (F-TWJ-T, Figure 2A) was stirred in absence (control wells) or presence of 5 mol. equiv. $(1.0 \mu \mathrm{M})$ of ligands and heated from 25 to $90{ }^{\circ} \mathrm{C}\left(1{ }^{\circ} \mathrm{C} /\right.$ step $)$. The thermal stability of F-TWJ-T, expressed as its temperature of mid-transition $T_{1 / 2}$ (here, $T_{1 / 2}=51.0{ }^{\circ} \mathrm{C}$ in absence of ligand) sharply increased in presence of the ligands (with $\Delta T_{1 / 2}=19.7,16.8$ and $15.7{ }^{\circ} \mathrm{C}$ for 4, $4^{\prime}$-TrisBP, TrisPOB and TrisPSB, respectively, versus $14.0{ }^{\circ} \mathrm{C}$ for $3,3^{\prime}$-TrisBP). Experiments 
were subsequently performed in presence of increasing concentrations (up to 50 mol. equiv.) of unlabeled competitors, either the duplex ds26 (i.e., the self-complementary

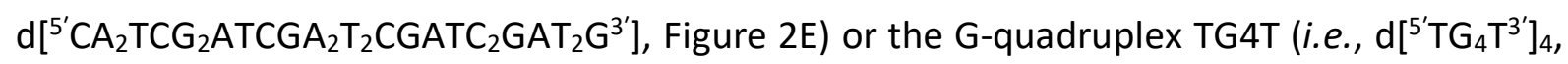
Figure $2 \mathrm{~F}$ ). These two competitors were selected in light of their high thermal stability in the conditions of the assays, which is $>20^{\circ} \mathrm{C}$ higher than that of F-TWJ-T $\left(T_{m}=70.5^{\circ} \mathrm{C}\right.$ for ds $26,{ }^{56}$ and $85^{\circ} \mathrm{C}$ for TG4T), ${ }^{57}$ meaning that they remain folded at temperatures at which both F-TWJT and F-TWJ-T/ligand complexes melt, thus providing a reliable and fierce competition. ${ }^{56-57}$ The capacity of a ligand to withstand the excess of competitor (comp.) was expressed as ${ }^{\text {FRETS }}$

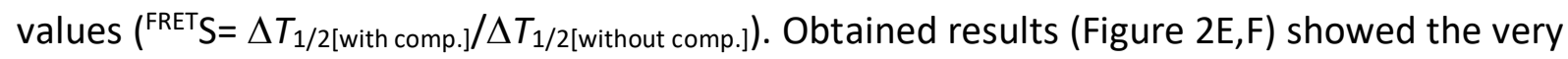
high TWJ-selectivity of the ligands against excess of both duplex and quadruplex, with ${ }^{\text {FRET }} \mathrm{S}=$ 0.94, 0.95 and 0.98 for 4,4'-TrisBP, TrisPOB and TrisPSB, respectively, versus 0.91 for 3,3'TrisBP in presence of 50 mol. equiv. of ds 26 , and ${ }^{\text {FRET } S}=0.65,0.73$ and 0.71 for $4,4^{\prime}$-TrisBP, TrisPOB and TrisPSB, respectively, versus 0.66 for 3,3'-TrisBP in presence of 50 mol. equiv. of TG4T. The intramolecular G-quadruplex 22AG (i.e., $\mathrm{d}\left[{ }^{5^{\prime}} \mathrm{AG}_{3}\left(\mathrm{~T}_{2} \mathrm{AG}_{3}\right)_{3}{ }^{\left.3^{\prime}\right]}\right]$ ) was also used as an example of biologically relevant competitor (mimicking the human telomeric sequence) and provided less fierce competition (with ${ }^{\text {FRETS }}$ values between 0.78 and 0.94 in presence of 50 mol. equiv. of 22AG, Figure S2). This series of competitive assays highlighted the good-toexquisite selectivity of these candidates for TWJ versus canonical (duplex-DNA) and another unusual DNA structures (quadruplex-DNA).

Finally, the TWJ affinity was quantified via electrospray ionization mass spectrometry (ESI-MS). ${ }^{42,58-59}$ Investigations were performed with the same pre-folded TWJ as the one used for FRET-melting investigations but devoid of the fluorescent label (Figure 2A). Measurements were performed with TWJ in absence (control) or presence of ligand ( 1 mol. equiv.). Results seen in Figure $2 \mathrm{G}$ demonstrated the very high affinity of the ligand for TWJ since only the 1:1 TWJ/ligand complexes were found for $4,4^{\prime}$-TrisBP, TrisPOB and TrisPSB (no free DNA was detectable), while small amounts of unbound DNA were still detectable with 3,3'-TrisBP. The quantification of these interactions via the calculation of the apparent equilibrium association constants $(K)$ was therefore unreliable, except for 3,3'-TrisBP $\left(K=1.9 \times 10^{6} \mathrm{M}^{-1}\right.$ at $1: 1$ ligand:DNA ratio, versus $3.9 \times 10^{6} \mathrm{M}^{-1}$ at 2:1 ligand:DNA ratio in ${ }^{42}$ ), with $\mathrm{K}$ values estimated $>10^{8} \mathrm{M}^{-1}$. These results, without being precisely quantifiable, are in line with other in vitro data collected so far and confirm the very high affinity of the four candidates for TWJ. 
Cytotoxicity and immunodetection of DNA damage. The antiproliferative properties of the four compounds against human breast carcinoma MCF-7 cells was assessed via the sulforhodamine $B(S R B)$ assay. ${ }^{60}$ The new ligands were found more active than the parent compound, with $\mathrm{IC}_{50}=0.67,0.94$ and $0.93 \mu \mathrm{M}$ for 4,4'-TrisBP, TrisPOB and TrisPSB, respectively (Figure $3 \mathrm{~A}$ ), versus $1.30 \mu \mathrm{M}$ for 3,3'-TrisBP (upon 72-h incubation).
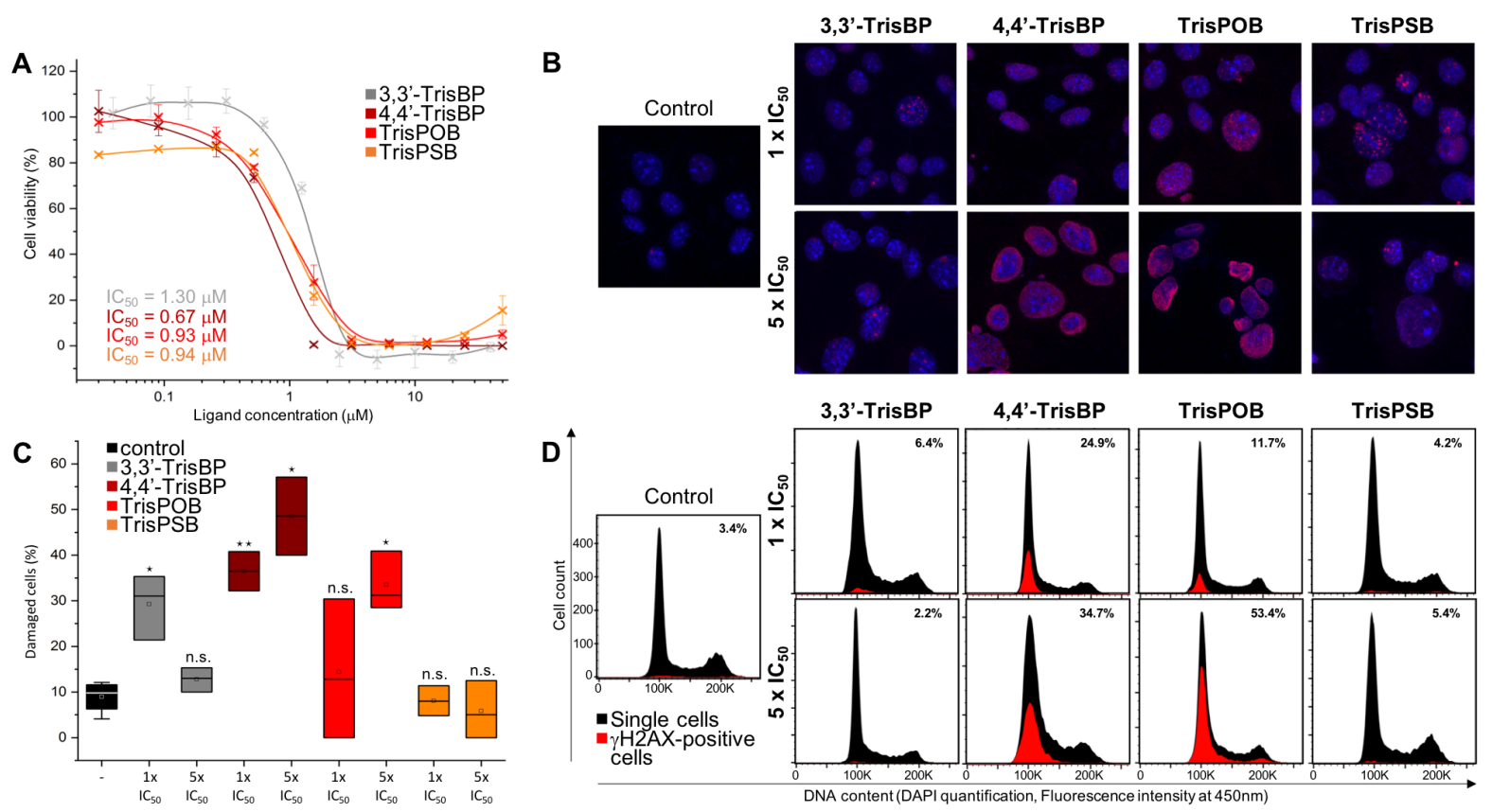

Figure 3. A. Antiproliferative activity of 3,3'-TrisBP, 4,4'-TrisBP, TrisPOB and TrisPSB assessed via the SRB assay, after MCF7 incubation for $72 \mathrm{~h}$ at $37^{\circ} \mathrm{C}$. B. Qualitative immunodetection of DNA damage in MCF7 cells untreated (control) or treated with $1 x(1.30,0.67,0.94$ and $0.93 \mu \mathrm{M})$ or $5 x \mathrm{IC}_{50}(6.5,3.35,4.7$ and $4.6 \mu \mathrm{M})$ of 3,3'-TrisBP, $4,4^{\prime}$-TrisBP, TrisPOB and TrisPSB for $4 \mathrm{~h}$ at $37^{\circ} \mathrm{C}$ prior to immunolabelling with antibodies raised against $\gamma \mathrm{H} 2 \mathrm{AX}$ (secondary antibodies labelled with AF647, $\lambda_{\mathrm{em}}=670 \mathrm{~nm}$ ) and DAPI nuclear staining $\left(\lambda_{\mathrm{em}}=450 \mathrm{~nm}\right)$. C. Quantification of the $\gamma \mathrm{H} 2 \mathrm{AX}$-positive MCF7 cells (percentage of cells with $>10 \gamma \mathrm{H} 2 \mathrm{AX}$ foci; manually counted cells, between 160 and 250 cells/conditions, in 3 different fields, with 21 cells/field on average) either untreated (control) or treated with $1 \mathrm{x}$ and $5 \mathrm{xIC}_{50}$ of 3,3'-TrisBP, 4,4'-TrisBP, TrisPOB and TrisPSB for $4 \mathrm{~h}$. ANOVA statistical analysis, with n.s. for non-significant, ${ }^{\star} p<0.01$ and ${ }^{\star \star} p<0.001$. D. Flow cytometry results of experiments performed with MCF7 cells (automatically counted cells, between 10500 and 15300 cells/conditions) incubated with either $1 x(1.30,0.67,0.94$ and $0.93 \mu \mathrm{M})$ or $5 x \mathrm{IC}_{50}(6.5,3.35,4.7$ and $4.6 \mu \mathrm{M})$ of 3,3'-TrisBP, 4,4'-TrisBP, TrisPOB and TrisPSB $\left(4 \mathrm{~h}, 37^{\circ} \mathrm{C}\right.$ ) prior to immunolabelling with antibodies raised against $\gamma \mathrm{H} 2 \mathrm{AX}$ (secondary antibodies labelled with AF647, $\lambda_{\mathrm{em}}=670 \mathrm{~nm}$ ) and DAPI nuclear staining $\left(\lambda_{\mathrm{em}}=450 \mathrm{~nm}\right)$. The percentage of $\gamma \mathrm{H} 2 \mathrm{AX}$-positive cells (with a fluorescence intensity at $670 \mathrm{~nm}$ greater than in the control condition, as defined based on a gate above the bulge of the control cell population) are indicated in the insets.

We next investigated whether these effects originated from DNA damage. To this end, we performed immunodetection studies using antibodies raised against the DNA damage marker $\gamma \mathrm{H} 2 \mathrm{AX} .{ }^{61} \mathrm{MCF} 7$ cells were treated for $4 \mathrm{~h}$ with either $1 \mathrm{x}$ or $5 \mathrm{x} I \mathrm{C}_{50}$ of $3,3^{\prime}$-TrisBP, $4,4^{\prime}-$ TrisBP, TrisPOB and TrisPSB, fixed and immunostained with a primary anti- $\gamma \mathrm{H} 2 \mathrm{AX}$ antibody (2-h 
incubation) followed by an Alexa Fluor 647 (AF647)-labeled secondary antibody (45-min incubation), prior to be mounted and imaged. As seen in Figures 3B, all 4 ligands induced DNA damage, with 3,3'-TrisBP and TrisPSB inducing a small number of discrete nuclear $\gamma \mathrm{H} 2 \mathrm{AX}$ foci and 4,4'-TrisBP and TrisPOB inducing a pan-nuclear staining evocative of a large amount of DNA damage. Quantification of the number of cells showing DNA damage signal confirmed these results (Figure 3C), with 3,3'-TrisBP and TrisPSB treatment resulting in a maximum of 29 and $8 \%$ of $\gamma \mathrm{H} 2 \mathrm{AX}$-positive cells (i.e., those with $>10$ foci per cell), while 4,4'-TrisBP and TrisPOB treatment resulted in a maximum of 48 and $33 \%$ of $\gamma \mathrm{H} 2 \mathrm{AX}$-positive cells. Of note, the percentage of cells showing DNA damage for both 4,4'-TrisBP and TrisPOB was increased with the drug concentration while it decreased for 3,3'-TrisBP and TrisPSB, suggesting that high concentrations of 3,3'-TrisBP and TrisPSB could interfere with DNA damage signaling itself. Not all cells were damaged upon treatment, suggesting that DNA damage could be induced at a specific stage of the cell cycle. To investigate this, flow cytometry was performed with MCF7 cells treated with the four ligands at both $1 \mathrm{x}$ and $5 \mathrm{x} I \mathrm{C}_{50}$ as above, the measurements being performed after 4-h live-cell incubation. Collected results seen in Figure 3D showed that the level of $\gamma \mathrm{H} 2 \mathrm{AX}$-positive cells did not steadily increase with the ligand concentration, confirming the classification of the ligands in two categories with 3,3'-TrisBP (6.4 and 2.2\% for $1 \mathrm{x}$ and $5 \times 1 \mathrm{C}_{50}$, respectively) and TrisPSB (4.2 and 5.4\%) on one side, and 4,4'-TrisBP (24.9 and 34.7\%) and TrisPOB (11.7 and 53.4\%) on the other side. These results also highlighted that for the two promising ligands $4,4^{\prime}$-TrisBP and TrisPOB, DNA damage was induced mainly in G1/early S-phases, which suggest an ability to trigger both replication- and transcriptionassociated DNA damage (vide infra).

Chemically induced synthetic lethality strategy. In light of their capability to trigger DNA damage, we next investigated whether the action of the four ligands can be potentiated by inhibitors of DNA repair (Figure 4A), according to an approach known as chemically induced synthetic lethality. ${ }^{47}$ We selected inhibitors of proteins involved in DNA repair via both the homologous recombination (HR) or the non-homologous end-joining (NHEJ) mechanisms, the two main DNA double-strand break (DSB) repair pathways. ${ }^{62-63}$ Specifically, we used NU7441, hereafter refer to as DNA-PKi given that it is a specific inhibitor of the DNA-dependent protein kinase (DNA-PK) involved in the detection and repair of DNA double-strand break (DSB) via NHEJ; ${ }^{64}$ KU55933, hereafter refer to as ATMi given that it is a specific inhibitor of the ATM 
(ataxia-telangiectasia mutated) kinase that orchestrates the cellular response to DSB, including DNA repair via HR and checkpoint activation; ${ }^{65}$ and $\mathrm{B} 02$, hereafter referred to as RAD51i given that it is an inhibitor of the recombinase RAD51, which plays a central role in DSB repair by HR. ${ }^{66}$ We investigated the inhibition of these two pathways given that NHEJ repairs most DSBs with the notable exception of DNA damage that occurs at the replication fork, which then involved preferentially HR. ${ }^{67}$ Inspired by the comprehensive work of T. C. Chou, ${ }^{68}$ we used the normalized isobolograms for combination ratios to study the possible synergy between TWJ ligands and DNA repair inhibitors. This representation is a dose-oriented graph with equipotency sum of concentrations, particularly suited for the combination of two drugs. MCF7 cells were cultured in matrix combinations of inhibitor and ligand serial dilutions (see Materials \& Methods). The cell viability was measured after $72 \mathrm{~h}$ (SRB assay) and the IC $\mathrm{C}_{50}$ values (also called $D_{m}$, for median-effect dose) were determined for each inhibitor: ligand ratio and reported as normalized isobolograms seen in Figure 4B-E. These results highlighted the better performances of TrisPOB as compared to the other ligands. Indeed, co-treatment of TrisPOB with the three inhibitors led to clearly synergistic effects $\left(\mathrm{IC}_{50}\right.$ values below the gray line that represents additivity) while co-treatment of the other ligands with the three inhibitors led to roughly additive (e.g., combination of RAD51i with 3,3'-TrisPB, 4,4'-TrisBP and TrisPSB, of DNA-PKi with 4,4'-TrisBP and TrisPSB) to antagonistic interactions (e.g., combination of DNA-PKi with 3,3'-TrisPB, of ATMi with 3,3'-TrisPB, 4, $4^{\prime}$-TrisBP and TrisPSB). To further characterize these effects, the combination index $(\mathrm{Cl} \text {, see Materials \& Methods })^{69}$ was calculated for each ratio, with $\mathrm{Cl}<1,=1$ and $>1$ giving evidence of synergistic, additive and antagonistic effects, respectively. As seen in Figure $4 \mathrm{~F}, \mathrm{Cl}$ values confirmed the clearly synergistic effects of the combination of TrisPOB and inhibitors (with $\mathrm{Cl}=0.80-1.01$ with DNAPKi, 0.72-0.93 for with ATMi, and 0.58-0.90 with RAD51i), and the roughly additive ( $\mathrm{Cl}$ between 0.85 and 1.11 for 3,3'-TrisBP + RAD51i and 4,4'-TrisBP + RAD51i; 0.93-1.06 for 4,4'-TrisBP + DNA-PKi; 0.86-1.07 for TrisPSB + DNA-PKi; 0.79-1.05 for TrisPSB + RAD51i, Figure 4F) to antagonistic interactions of all other combinations $(\mathrm{Cl}=1.00-1.21$ for 3,3'-TrisBP + DNA-PKi; 1.00-1.18 for 3,3'-TrisBP + ATMi; 1.00-1.21 for 4,4'-TrisBP + ATMi; 0.93-1.08 for TrisPSB + ATMi). The synergistic interactions of TrisPOB with DNA repair inhibitors were also investigated by plotting 3D surface graphs. In this representation, the concentrations of two chemicals are reported on the $x$ - and $y$-axes, and the effect of the combination reported on the $z$-axis as the percentage of additional growth inhibition compared to the single agent 
controls. ${ }^{70}$ 3D surface graphs seen in Figures $4 \mathrm{G}$ highlighted that the most pronounced effect is obtained for the highest concentration of the inhibitors, with the notable exception of the TrisPOB/RAD51i combination that provided a good synergy (>60\%) with a low concentration of RAD51i $(0.47 \mu \mathrm{M})$, thus highlighting the particular relationship between these two agents. Collectively, these results confirmed that TWJ ligands trigger DNA damage, more specifically DNA DSBs since the NHEJ DNA repair pathway only handle this type of DNA lesions. In addition, they confirm that the antiproliferative effects of TWJ ligands (that create DNA damage) can be synergistically potentiated by DNA repair inhibitors (that impede proper DNA damage management).

A

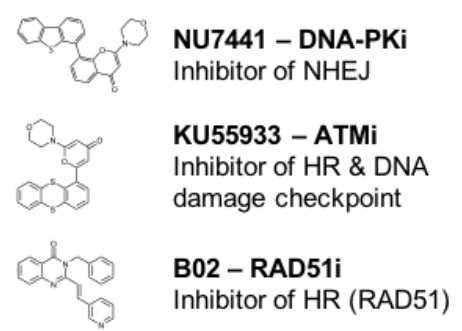

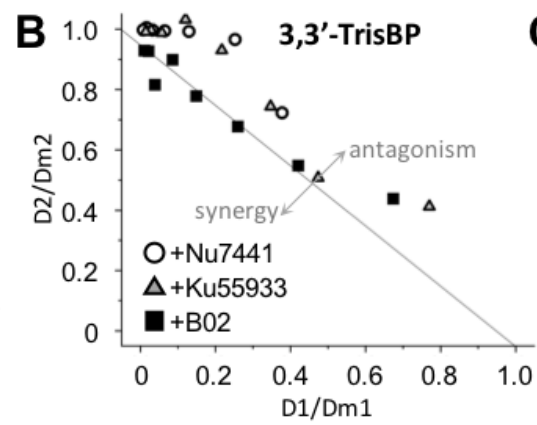
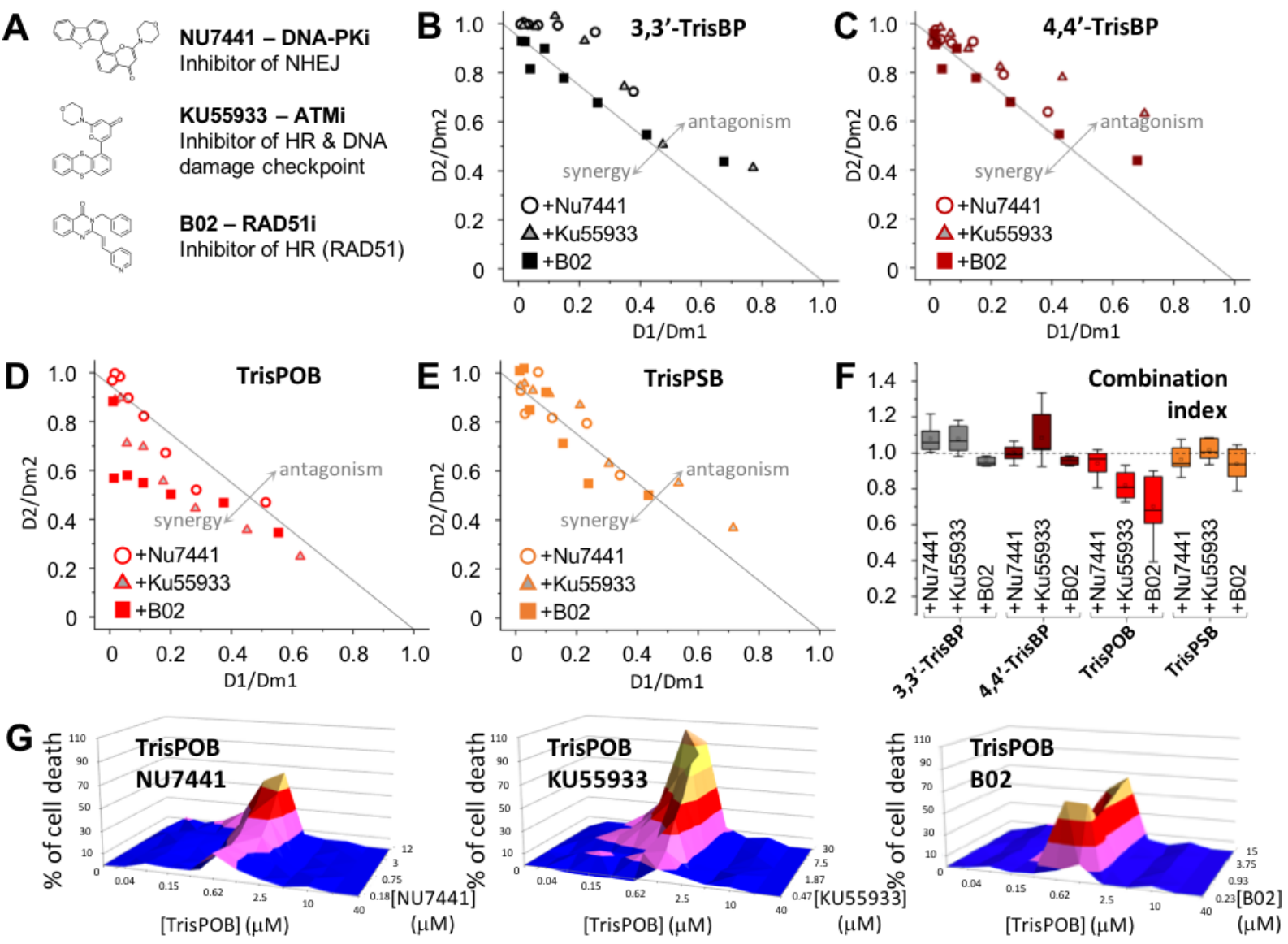

Figure 4. A. Chemical structure of NU7441, KU55933 and B02. B-E. Normalized isobolograms for combination of 3,3'-TrisBP (B), 4,4'-TrisBP (C), TrisPOB (D) and TrisPSB (E) with DNA-PKi (circles), ATMi (triangles) and RAD51i (squares). The gray oblique line indicates additive effects; antagonistic effects on the right of this line, synergistic effects on the left. F. Combination index graphs of combinations of 3,3'-TrisBP (grey), 4, 4'-TrisBP (brown), TrisPOB (red) and TrisPSB (orange) with DNA-PKi, ATMi and RAD51i. G. 3-D surface plots for the combination of TrisPOB, from 0 to $40 \mu \mathrm{M}$, with DNA-PKi (from 0 to $12 \mu \mathrm{M}$ ), ATMi (from 0 to $30 \mu \mathrm{M}$ ) or RAD51i (from 0 to $15 \mu \mathrm{M}$ ). 


\section{Discussion}

To date, the possible therapeutic interest of DNA junctions and related ligands are being harnessed to a limited extent only, mostly because of the lack of a firm demonstration of their actual strategic relevance. The targeting of DNA junctions traces back to the late 1980s, with the comprehensive works of N. R. Kallenbach and coworkers. ${ }^{71-73}$ From lab curiosity, this field became an intensive research area thanks to the impetus provided by the pioneering works of M. J. Hannon and coworkers, ${ }^{40,44-45,74-75}$ which laid solid foundations for the design of efficient TWJ ligands. To date, only few families of compounds have been studied for their ability to interact specifically with TWJ, including Hannon's supramolecular cylinders (vide supra) along with poly-aza-macrocyles, ${ }^{55,} 76$ triptycene derivatives, ${ }^{77-78}$ azacryptands, ${ }^{43}$ azacyclophanes and metallacages, ${ }^{41}$ and calix[3]carbazoles. ${ }^{79}$ In the present work, we go a step further demonstrating that TWJ ligands do have therapeutic value, showing that finely selected TWJ ligands damage DNA in human cancer cells and are amenable to chemically induced synthetic lethality strategies upon association with inhibitors of DNA repair.

Inspired by the wealth of data that show how quadruplex ligands trigger DNA damage via the formation of double-strand breaks (DSBs) by stabilizing physical roadblocks to polymerase translocations, we decided to investigate whether stabilized DNA junctions might act as DNA transaction impediments as well. We demonstrated that the azacryptands 3,3'TrisBP, 4, $4^{\prime}$-TrisBP, TrisPOB and TrisPSB do kill cancer cells efficiently (with $\mathrm{IC}_{50}$ values lower than $1.30 \mu \mathrm{M})$. We also showed that caution must be exercised when interpreting in vitro results given that two ligands that display very promising DNA-interacting properties in vitro (3,3'-TrisBP and TrisPSB) exert their antiproliferative effect in a DNA damage-independent manner. This observation indicates that these two ligands have alternative targets in cells: RNA TWJs might be putative candidates, as they are known to be widespread in the transcriptome and responsible for the functions of cellular RNAs. ${ }^{80-83}$ Even if the central cavity is far broader in RNA than in DNA TWJ, it can accommodate small molecules, such as di-iron supramolecular cylinders ${ }^{84}$ and triptycene derivatives, ${ }^{77}$ albeit with lower affinity as compared to their DNA counterparts. To explore this issue, we assessed the capacity of the azacryptands to interact with RNA TWJ via adapted versions of the TWJ-Screen, FRET-melting and ESI-MS assays: the former is not ideally suited to RNA TWJ given that the three separated RNA strands spontaneously self-associate in the conditions of the assay to a large extent $\left(\mathrm{NFI}_{\mathrm{M}}=-43 \%\right.$ as compared to $\mathrm{NFI}_{\mathrm{FAM}-\mathrm{TW}-\mathrm{RNA}-\mathrm{S} 1}$, Figure $\mathrm{S} 4$ ). However, the values of $\mathrm{NFI}_{\mathrm{M}-[\mathrm{M}+\text { ligand] }}$ (between +1 and 
$-9 \%$ as compared to $\mathrm{NFI}_{\mathrm{M}}$ ) indicate the lower capability of the ligand to promote the folding of RNA TWJ as compared to DNA TWJ (NFI $\mathrm{M}_{\mathrm{M}-[\mathrm{M}+\text { ligand] }}$ between -15 and $-41 \%$ as compared to $\mathrm{NFI}_{\mathrm{M}}$, Figure 2B). This was confirmed by FRET-melting experiments performed with the doubly labeled RNA TWJ FAM-r $\left[{ }^{5} \mathrm{~A}(\mathrm{CU})_{2}(\mathrm{UC})_{2} \mathrm{G}-\mathrm{U}_{6}-\mathrm{C}(\mathrm{GA})_{2} \mathrm{GCGAC}-\mathrm{U}_{6}-\mathrm{GUCGC}(\mathrm{AG})_{2} \mathrm{U}^{3^{\prime}}\right]$-TAMRA (Figure S5) in presence of 5 mol. equiv. of ligands, for which a far weaker ligand-imparted stabilization was obtained (with $\Delta T_{1 / 2}$ values between 1 and $9{ }^{\circ} \mathrm{C}$ ) as compared to the DNA TWJ $\left(\Delta T_{1 / 2}\right.$ values between 14 and $20^{\circ} \mathrm{C}$ ). Finally, the ESI-MS investigations also confirmed the lower affinity of the azacryptands for RNA TWJ, with $K$ values at least 2 orders of magnitude lower than that calculated (or estimated) with DNA TWJ ( $K$ between $7.8 \times 10^{4}$ and $7.3 \times 10^{5} \mathrm{M}^{-1}$, Figure S6). Collectively, these results show that the azacryptands 3,3'-TrisBP and TrisPSB exert their antiproliferative effects via different pathways and targets that remain to be discovered. Contrarily, the efficacy of the both 4,4'-TrisBP and TrisPOB in killing MCF7 cells was attributed to DNA damage induction, as demonstrated by the accumulation of the marker $\gamma \mathrm{H} 2 \mathrm{AX}$ in treated cells. These results are in line with the studies of Hannon and co-workers that demonstrated that TWJ-binding supramolecular cylinders impede the processivity of DNA polymerases. ${ }^{85}$ The azacryptands were then included in drug combinations with inhibitors of DNA repair, focusing on both homologous recombination (HR) and non-homologous end joining (NHEJ) mechanisms as these two pathways are critical for DSBs repair. Synergistic relationships between the ligands and either NU7441 (a DNA-PKi that impairs NHEJ), KU55933 (that inhibits ATM and thus impairs DSB signaling and HR) or B02 (inhibitor of the RAD51 recombinase, a key enzyme for HR) were studied. Our results highlighted the excellent performances of TrisPOB to synergistically interact with DNA repair inhibitors, leading to drug combination exhibiting high efficiency in killing cancer cells, with combination index $(\mathrm{Cl})$ as low as 0.39 with RAD51i, 0.72 with ATMi and 0.80 with DNA-PKi. These results supported the hypothesis according to which TrisPOB triggers both transcription- and replication-associated DNA damage, given that its effect was potentiated by inhibition of both NHEJ (the main repair mechanism for DSBs) and HR (a repair mechanism handling replication-associated singleended DSBs). This hypothesis was further substantiated by the excellent synergy with RAD51i $(\mathrm{Cl}$ down to 0.39 , average $\mathrm{Cl}=0.70$, Figure $4 \mathrm{~F})$, given that RAD51 is an early responder to replication fork stalling ${ }^{86}$ and a key player in the repair of transcription-coupled DSBs. ${ }^{25}$ The flow cytometry profiles seen in Figure 3D, with DNA damage induced mostly at the G1/S transition, were also in line with this hypothesis given that DNA replication is promoted during 
the G1 phase by cyclin-dependent kinase (CDK, which also initiate G1-to-S phase transition), and because of the general importance of checkpoint regulation of $\mathrm{G} 1 / \mathrm{S}$ transcription in response to replicative stress. Interestingly, the exquisite relationship between TrisPOB and ATMi is highly valuable given that ATM is dysregulated in many cancer types, ${ }^{87-88}$ thus providing novel therapeutic opportunities.

Altogether, these results paved a new way toward promising drug cocktails to fight against cancer cells proliferation. They also provided a message of caution when investigating the effects of cell-permeable small molecules given that they might alter multiple key cellular mechanisms simultaneously, and to various extent, making the analysis of the origins of their anticancer activities challenging, if not daunting. The DNA junction ligands described here indeed belong to a wide family of compounds (azacyclophanes, azacryptands) known to target abasic sites and trigger DNA cleavage and/or inhibition of base-excision DNA repair. ${ }^{89-90}$ As discussed above, other higher-order nucleic acid structures (notably, RNA TWJ) are possible targets, along with the myriad of putative protein targets found in cells. We have made here every effort to connect in vitro results (describing TWJ-interacting properties) to cell-based effects, which has proved true for some ligands (4,4'-TrisBP and TrisPOB) and inaccurate for others (3,3'-TrisBP and TrisPSB). The multiplicity of putative intracellular targets might yield real therapeutic dividends but it requires both the need to exercise caution and care when interpreting cell-based results and further efforts and new molecular tools to precisely unravel the origins of the global cellular response monitored.

In conclusion, these results thus add another arrow in the quiver of drug cocktails that must be thought about when fighting against cancer cell proliferation. We believe that TrisPOB represents the first, reliable prototype of therapeutically active DNA junction ligands and provides the requested proof-of-principle that TWJ ligand have excellent potential as antiproliferative agents.

\section{Materials \& Methods}

Chemistry. All commercially available chemicals were reagent grade and used without further purification. 4,4'-Thiobis(benzaldehyde) was prepared in a $22 \%$ yield by following the published procedure. ${ }^{91}$ NMR spectra were recorded with a Bruker Avance 300 spectrometer $\left({ }^{1} \mathrm{H}: 300 \mathrm{MHz},{ }^{13} \mathrm{C}: 75 \mathrm{MHz}\right)$ at $25^{\circ} \mathrm{C}$. Chemical shifts are given in ppm $(\delta)$ values and calibrated with respect to the signal of TMS $\left(\mathrm{CDCl}_{3}\right)$ or $\mathrm{MeOH}\left(\mathrm{D}_{2} \mathrm{O} ; \delta_{\mathrm{H}}=3.34, \delta_{\mathrm{C}}=49.50 \mathrm{ppm}\right)$. 
Multiplicities of ${ }^{13} \mathrm{C}$ NMR signals were determined from DEPT135 experiments. Elemental microanalysis of all novel compounds was performed by Service de Microanalyse at ICSN, Gifsur-Yvette, France. The purity of final compounds was assessed by HPLC analysis on a DIONEX UltiMate 3000 system equipped with a Waters Atlantis T3 column $(100 \times 3 \mathrm{~mm}$, particle size: $3 \mu \mathrm{m}$ ) and a UV detector operating at $254 \mathrm{~nm}$. Eluent A: water with 0.01\% TFA, eluent B: MeCN with $0.01 \%$ TFA, linear gradient elution with 0 to $100 \%$ of eluent $B$, flow rate: $0.6 \mathrm{~mL} \mathrm{~min}$. $^{-1}$. ESI-MS (positive-ion mode) were recorded with a Waters ZQ instrument. MALDI-TOF-MS were recorded at the Small Molecule Mass Spectrometry platform of ICSN, Gif-sur-Yvette, France.

Synthesis of hexaimine intermediates 1a-c (Scheme S1): A solution of a dialdehyde (3.00 $\mathrm{mmol}$ ) in MeCN (150 mL) was added dropwise to a vigorously stirred solution of tris(2aminoethyl)amine $(2.00 \mathrm{mmol})$ in $\mathrm{MeCN}(100 \mathrm{~mL})$. The reaction mixture was stirred at room temperature for 7 days and then concentrated in vacuum to a half of its initial volume. The precipitated solid was collected, thoroughly washed with $\mathrm{MeCN}$, and dried in vaccum, to give the hexaimine intermediate $(\mathbf{1} \mathbf{a}-\mathbf{c})$ which was sufficiently pure and used in the next step without further purification. Compound 1a: Yield 96\%. Yellow solid; the spectroscopic properties were in agreement with the literature data. ${ }^{50}$ Compound 1b: Yield 99\%. Off-white solid; the spectroscopic properties were in agreement with the literature data. ${ }^{50}$ Compound 1c: Yield 99\%. Pale-yellow solid; ${ }^{1} \mathrm{H}$ NMR $\left(300 \mathrm{MHz}, \mathrm{CDCl}_{3}\right): \delta 2.89$ (d, J=4.1 Hz, 2H), 3.53 (d, J $=5.5 \mathrm{~Hz}, 2 \mathrm{H}$ ), 7.11 (d, J = 8.2 Hz, 2H), 7.44 (d, J=8.2 Hz, 2H), 7.59 (s, 1H); HRMS (MALDI-TOF, matrix: DCTB) $m / z\left[M+\mathrm{H}^{+}\right]$calcd. for $\mathrm{C}_{54} \mathrm{H}_{54} \mathrm{~N}_{8} \mathrm{~S}_{3}$ : 911.3706; found: 911.3725 .

Synthesis of azacryptands $\mathbf{2} \boldsymbol{a}-\boldsymbol{b}$ : Sodium borohydride $(15 \mathrm{mmol})$ was added to a stirred suspension of $1 \mathbf{a}-\mathbf{b}(0.5 \mathrm{mmol})$ in a mixture of $\mathrm{CH}_{2} \mathrm{Cl}_{2}(30 \mathrm{~mL})$ and $\mathrm{MeOH}(15 \mathrm{~mL})$. After stirring for $6 \mathrm{~h}$ at room temperature, aq. $\mathrm{NaOH}(1 \mathrm{M}, 20 \mathrm{~mL})$ was added. The organic phase was separated, and the aqueous phase was extracted with chloroform $(3 \times 20 \mathrm{~mL})$. The combined organic phases were washed with satd. aq. $\mathrm{Na}_{2} \mathrm{CO}_{3}(20 \mathrm{~mL})$, dried over $\mathrm{K}_{2} \mathrm{CO}_{3}$ and the solvent was removed in vacuum, to give the crude azacryptand, which was further purified by flash chromatography ( $\mathrm{SiO}_{2}$, eluent: $\mathrm{CH}_{2} \mathrm{Cl}_{2}-\mathrm{MeOH}$-aq. $\mathrm{NH}_{4} \mathrm{OH}, 80: 20: 0$ to 80:20:4). Compound 2a was additionally recrystallized from hot pyridine. Compound 2a (4,4'-TrisBP): Yield $269 \mathrm{mg}$ (65\%); pale yellow solid, ${ }^{1} \mathrm{H}$ NMR ( $\left.\mathrm{CDCl}_{3}\right)$ : $\delta 1.93$ (br s, $\left.1 \mathrm{H}, \mathrm{NH}\right), 2.73(\mathrm{~m}, 2 \mathrm{H}), 2.93(\mathrm{~m}, 2 \mathrm{H}), 3.78$ $(\mathrm{s}, 2 \mathrm{H}), 6.96(\mathrm{~d}, J=8.0 \mathrm{~Hz}, 2 \mathrm{H}), 7.08(\mathrm{~d}, J=8.1 \mathrm{~Hz}, 2 \mathrm{H}) ;{ }^{13} \mathrm{C} \mathrm{NMR}\left(75 \mathrm{MHz}, \mathrm{CDCl}_{3}\right): \delta 47.6\left(\mathrm{CH}_{2}\right)$, 52.6 $\left(\mathrm{CH}_{2}\right), 54.4\left(\mathrm{CH}_{2}\right), 126.9(\mathrm{CH}), 128.1(\mathrm{CH}), 138.8\left(\mathrm{C}_{\mathrm{q}}\right), 138.9\left(\mathrm{C}_{\mathrm{q}}\right) ; \mathrm{MS}\left(\mathrm{ESI}^{+}\right): \mathrm{m} / \mathrm{z}=827.7[\mathrm{M}$ $+\mathrm{H}^{+}$]; purity (HPLC): 99\%; anal. calcd. (\%) for $\mathrm{C}_{54} \mathrm{H}_{66} \mathrm{~N}_{8} \times 0.5 \mathrm{H}_{2} \mathrm{O}$ (836.2): $\mathrm{C}$ 77.57; $\mathrm{H}$ 8.08; $\mathrm{N}$ 
13.40; found: C, 77.66; H, 7.88; N, 13.40. Compound 2b (TrisPOB): Yield 257 mg (59\%); colorless solid, ${ }^{1} \mathrm{H}$ NMR (CDCl 3$): \delta 1.62$ (br s, $\left.1 \mathrm{H}, \mathrm{NH}\right), 2.66$ (d, $\left.J=5.5 \mathrm{~Hz}, 2 \mathrm{H}\right), 2.74$ (d, $J=5.4$ $\mathrm{Hz}, 2 \mathrm{H}), 3.62(\mathrm{~s}, 2 \mathrm{H}), 6.67(\mathrm{~d}, J=8.5 \mathrm{~Hz}, 2 \mathrm{H}), 6.96(\mathrm{~d}, J=8.5 \mathrm{~Hz}, 2 \mathrm{H}) ; \mathrm{MS}\left(\mathrm{ESI}^{+}\right): \mathrm{m} / \mathrm{z}=875.7[M$ $\left.+\mathrm{H}^{+}\right]$; purity (HPLC): $97 \%$.

Synthesis of azacryptand 2c: Sodium borohydride (340 mg, $9 \mathrm{mmol}$ ) was added to a stirred suspension of $1 \mathrm{c}(273 \mathrm{mg}, 0.3 \mathrm{mmol})$ in a mixture of $\mathrm{CH}_{2} \mathrm{Cl}_{2}(50 \mathrm{~mL})$ and $\mathrm{MeOH}(25 \mathrm{~mL})$. After stirring for $6 \mathrm{~h}$ at room temperature, aq. $\mathrm{NaOH}(1 \mathrm{M}, 30 \mathrm{~mL})$ was added. The organic phase was separated, and the aqueous phase was extracted with chloroform $(3 \times 30 \mathrm{~mL})$. The combined organic phases were washed with satd. aq. $\mathrm{Na}_{2} \mathrm{CO}_{3}(20 \mathrm{~mL})$, dried over $\mathrm{K}_{2} \mathrm{CO}_{3}$ and the solvents were removed in vacuum. Purification by flash chromatography $\left(\mathrm{SiO}_{2}\right.$, eluent: $\mathrm{CH}_{2} \mathrm{Cl}_{2}-\mathrm{MeOH}$-aq. $\mathrm{NH}_{4} \mathrm{OH}, 80: 20: 0$ to 80:20:4) gave compound 2c (TrisPSB) (152 mg, 55\%) as a yellow solid; ${ }^{1} \mathrm{H} \mathrm{NMR}\left(\mathrm{CDCl}_{3}\right): \delta=1.96(\mathrm{br} \mathrm{s}, 1 \mathrm{H}), 2.59(\mathrm{~d}, J=4.7 \mathrm{~Hz}, 2 \mathrm{H}), 2.64(\mathrm{~d}, J=4.8 \mathrm{~Hz}$, $2 \mathrm{H}), 3.55(\mathrm{~s}, 2 \mathrm{H}), 7.04(\mathrm{~d}, J=8.2 \mathrm{~Hz}, 2 \mathrm{H}), 7.15(\mathrm{~d}, J=8.1 \mathrm{~Hz}, 2 \mathrm{H}) ; \mathrm{MS}\left(\mathrm{ESI}^{+}\right): m / z=923.8[M+$ $\mathrm{H}^{+}$; purity (HPLC): 98\%.

Preparation of hydrochloride salts $2 b \times 6 \mathrm{HCl}$ and $2 c \times 6 \mathrm{HCl}$ : The free-base azacryptand (0.12 mmol) was dissolved in 1,4-dioxane $(20 \mathrm{~mL})$, and excess $\mathrm{HCl}(1.25 \mathrm{M}$ in $\mathrm{MeOH}, 2.4 \mathrm{~mL})$ was added. The volatiles were removed in vaccum and the white residue was recrystallized in a mixture of $\mathrm{MeOH}-\mathrm{H}_{2} \mathrm{O}(\mathbf{2 b})$ or in aq. $0.5 \mathrm{M} \mathrm{HCl}(\mathbf{2 c})$ to give respectively $\mathbf{2 b} \times 6 \mathrm{HCl}$ and $\mathbf{2 c} \times$ $6 \mathrm{HCl}$ as white crystalline solids. $\mathbf{2 b} \times 6 \mathrm{HCl}\left(\right.$ TrisPOB $\times 6 \mathrm{HCl}$ ): Yield 89\%; colorless needles, ${ }^{1} \mathrm{H}$ $\operatorname{NMR}\left(\mathrm{D}_{2} \mathrm{O}\right): \delta 2.80(\mathrm{t}, J=5.6 \mathrm{~Hz}, 2 \mathrm{H}), 3.11(\mathrm{t}, J=5.5 \mathrm{~Hz}, 2 \mathrm{H}), 4.16(\mathrm{~s}, 2 \mathrm{H}), 7.07(\mathrm{~d}, J=8.6 \mathrm{~Hz}$, $2 \mathrm{H}), 7.44(\mathrm{~d}, J=8.6 \mathrm{~Hz}, 2 \mathrm{H}) ;{ }^{13} \mathrm{C} \mathrm{NMR}\left(75 \mathrm{MHz}, \mathrm{D}_{2} \mathrm{O}\right): \delta 45.1\left(\mathrm{CH}_{2}\right), 50.7\left(\mathrm{CH}_{2}\right), 51.2\left(\mathrm{CH}_{2}\right), 120.1$ (CH), $126.5\left(\mathrm{C}_{q}\right), 132.8(\mathrm{CH}), 158.0\left(\mathrm{C}_{q}\right)$; purity (HPLC): 98\%; anal. calcd. (\%) for $\mathrm{C}_{54} \mathrm{H}_{66} \mathrm{Cl}_{6} \mathrm{~N}_{8} \mathrm{O}_{3} \times$ $6 \mathrm{HCl} \times 8 \mathrm{H}_{2} \mathrm{O}(1238.0): \mathrm{C}, 52.39 ; \mathrm{H}, 7.16, \mathrm{~N}, 9.05$; found: $\mathrm{C}, 52.63 ; \mathrm{H}, 6.74 ; \mathrm{N}, 9.07 .2 \mathrm{c} \times 6 \mathrm{HCl}$ (TrisPSB $\times 6 \mathrm{HCl}$ ): Yield 92\%; pale-yellow needles, ${ }^{1} \mathrm{H} N M R\left(\mathrm{D}_{2} \mathrm{O}\right): \delta 2.78(\mathrm{t}, J=5.4 \mathrm{~Hz}, 2 \mathrm{H}), 3.09$ $(\mathrm{t}, J=5.4 \mathrm{~Hz}, 2 \mathrm{H}), 4.14(\mathrm{~s}, 2 \mathrm{H}), 7.39(\mathrm{~s}, 4 \mathrm{H}) ;{ }^{13} \mathrm{C} \mathrm{NMR}\left(75 \mathrm{MHz}, \mathrm{D}_{2} \mathrm{O}\right): \delta 45.2\left(\mathrm{CH}_{2}\right), 50.5\left(\mathrm{CH}_{2}\right)$, $51.3\left(\mathrm{CH}_{2}\right), 130.4\left(\mathrm{C}_{\mathrm{q}}\right), 131.9(\mathrm{CH}), 132.0(\mathrm{CH}), 137.1\left(\mathrm{C}_{\mathrm{q}}\right)$; purity (HPLC): 98\%; anal. calcd. (\%) for $\mathrm{C}_{54} \mathrm{H}_{66} \mathrm{~N}_{8} \mathrm{~S}_{3} \times 6 \mathrm{HCl} \times 8 \mathrm{H}_{2} \mathrm{O}$ (1286.2): C, 50.43; $\mathrm{H}, 6.90 ; \mathrm{N}, 8.71, \mathrm{~S}, 7.48$; found: $\mathrm{C}, 50.31 ; \mathrm{H}$, 6.53; N, 8.50; S, 7.64 .

Single-crystal X-ray diffraction analysis of TrisPOB $\times 6 \mathbf{H C l}$. X-ray quality crystals of $2 \mathbf{b} \times 6$ $\mathrm{HCl} \times \mathrm{MeOH}$ were obtained from a hot $\mathrm{MeOH}-\mathrm{H}_{2} \mathrm{O}$ solution. X-ray diffraction data for compound TrisPOB was collected by using a VENTURE PHOTON100 CMOS Bruker diffractometer with Micro-focus I $\mu$ S source CuK $\alpha$ radiation. Crystals were mounted on a 
CryoLoop (Hampton Research) with Paratone-N cryoprotector (Hampton Research) and then flash-frozen in a nitrogen-gas stream at $100 \mathrm{~K}$. The temperature of the crystal was maintained at $100 \pm 1 \mathrm{~K}$ by means of a 700 series Cryostream cooling device. The data were corrected for Lorentz polarization, and absorption effects. The structures were solved by direct methods using SHELXS-9792 and refined against $F^{2}$ by full-matrix least-squares techniques using SHELXL$2018^{93}$ with anisotropic displacement parameters for all non-hydrogen atoms. Hydrogen atoms, with the exclusion of those of solvation water and methanol, were located on a difference Fourier map and introduced into the calculations as a riding model with isotropic thermal parameters. All calculations were performed by using the Crystal Structure crystallographic software package WINGX. ${ }^{94}$ The crystal data collection and refinement parameters are given in Table S1. CCDC-1952718 contains the supplementary crystallographic data for this paper. These data can be obtained free of charge from the Cambridge Crystallographic Data Centre via https://www.ccdc.cam.ac.uk/structures/.

Oligonucleotides. The lyophilized DNA sequences purchased from Eurogentec ${ }^{\mathrm{TM}}$ (Belgium) were firstly diluted at $500 \mu \mathrm{M}$ in deionized water (18.2 M $\Omega . c m$ resistivity). The actual concentration of each DNA solution was determined after a dilution to $1 \mu \mathrm{M}$ theoretical concentration through UV spectral analysis at $260 \mathrm{~nm}$ (after $5 \mathrm{~min}$ at $90^{\circ} \mathrm{C}$ ) with the molar extinction coefficient values provided by the manufacturer. Separated strands (FAM-TWJ-S1, TWJ-S1, TWJ-S2, TWJ-S3-TAMRA and TWJ-S3) were subsequently diluted in a CacoK buffer (10 $\mathrm{mM}$ lithium cacodylate buffer plus $10 \mathrm{mM} \mathrm{KCl} / 90 \mathrm{mM} \mathrm{LiCl} \mathrm{pH} \mathrm{7.2)} \mathrm{at} 2 \mu \mathrm{M}$ for TWJ-Screen and $9 \mu \mathrm{M}$ for PAGE experiments. For FRET-melting experiments, F-TWJ-T was prepared by mixing $40 \mu \mathrm{L}$ of the constitutive strand $(500 \mu \mathrm{M})$ with $8 \mu \mathrm{L}$ of a lithium cacodylate buffer solution (100 $\mathrm{mM}, \mathrm{pH} 7.2)$, plus $8 \mu \mathrm{L}$ of a $\mathrm{KCl} / \mathrm{LiCl}$ solution $(100 \mathrm{mM} / 900 \mathrm{mM})$ and $24 \mu \mathrm{L}$ of water; ds 26 was prepared by mixing $40 \mu \mathrm{L}$ of the constitutive strand $(500 \mu \mathrm{M})$ with $16 \mu \mathrm{L}$ of a lithium cacodylate buffer solution (100 mM, pH 7.2), plus $16 \mu \mathrm{L}$ of a $\mathrm{KCl} / \mathrm{LiCl}$ solution $(100 \mathrm{mM} / 900 \mathrm{mM})$ and 48 $\mu \mathrm{L}$ of water; TG4T was prepared by mixing $20 \mu \mathrm{L}$ of the constitutive strand (1000 $\mu \mathrm{M})$ with 32 $\mu \mathrm{L}$ of a lithium cacodylate buffer solution (100 mM, pH 7.2), plus $32 \mu \mathrm{L}$ of a $\mathrm{KCl} / \mathrm{LiCl}$ solution (100 mM/900 mM) and $96 \mu \mathrm{L}$ of water. For ESI-MS analysis, the higher-order DNA structure was prepared by mixing $17 \mu \mathrm{L}$ of TWJ $(500 \mu \mathrm{M})$ with $17 \mu \mathrm{L}$ of ammonium acetate buffer $(1 \mathrm{M}$, $\mathrm{pH}$ 7.0) and $136 \mu \mathrm{L}$ of water. The higher-order structures were folded according to two procedures: (a) for F-TWJ-T (FRET-melting) and TWJ (ESI-MS), solutions were heated $\left(90^{\circ} \mathrm{C}, 5\right.$ min), cooled on ice (FRET-melting) or to $25{ }^{\circ} \mathrm{C}$ gradually (ESI-MS) and then stored at least 
overnight $\left(4{ }^{\circ} \mathrm{C}\right)$; (b) for TG4T and ds26, the solutions were heated $\left(90^{\circ} \mathrm{C}, 5 \mathrm{~min}\right)$, gradually cooled $\left(65,60,55,50,40\right.$ and $\left.30^{\circ} \mathrm{C}(60 \mathrm{~min} / \mathrm{step}), 25^{\circ} \mathrm{C}(2 \mathrm{~h})\right)$ and stored overnight $\left(4{ }^{\circ} \mathrm{C}\right)$.

TWJ-Screen assay. Experiments are performed in a 96-well format plate (Greiner, F-bottom black) using a BMG Labtech ClarioStar equipped with FAM filters $\left(\lambda_{\mathrm{ex}}=492 \mathrm{~nm} ; \lambda_{\mathrm{em}}=516 \mathrm{~nm}\right)$ at $37^{\circ} \mathrm{C}$. Experiments are performed in CacoK buffer $(10 \mathrm{mM}$ lithium cacodylate plus $10 \mathrm{mM}$ $\mathrm{KCl} / 90 \mathrm{mM} \mathrm{LiCl}, \mathrm{pH}$ 7.2, final volume: $100 \mu \mathrm{L} /$ well) with $1 \mu \mathrm{M}$ ligand and $0.2 \mu \mathrm{M}$ DNA (stepwise addition of $10 \mu \mathrm{L}$ of $2 \mu \mathrm{M}$ solution of FAM-TWJ-S1, TWJ-S2 and TWJ-S3-TAMRA). The microplate is centrifuged quickly (30 s) and then placed into the ClarioStar. The FAM fluorescence is monitored upon gentle stirring at $37{ }^{\circ} \mathrm{C}$ every 5 min during $1 \mathrm{~h}$. Final data are analysed by using Excel (Microsoft Corp.) and OriginPro ${ }^{\circledR} 9$ (OriginLab Corp.). The results are expressed as normalized fluorescence intensity (NFI) values collected at $60 \mathrm{~min}$. The efficiency of ligands to fold TWJ is quantified by comparing the NFI of FAM-TWJ-S1 alone (defined as 100\%) versus that of [FAM-TWJ-S1+ligand] (for discarding unwarranted ligand's interaction with FAM-TWJ-S1) on one hand, and the NFI of the mixture M ([FAM-TWJ-S1+TWJ-S2+TWJS3-TAMRA]) versus [M+ligand] (that quantifies the TWJ folding per se) on the other hand. Reported NFI values are means of 3 experiments.

FRET-melting assay. Experiments are performed in a 96-well format plate (Agilent) using an Agilent Stratagene Mx3005P equipped with FAM filters $\left(\lambda_{\mathrm{ex}}=492 \mathrm{~nm} ; \lambda_{\mathrm{em}}=516 \mathrm{~nm}\right)$ from 25 to $90{ }^{\circ} \mathrm{C}$. Experiments are performed in CacoK buffer $(10 \mathrm{mM}$ lithium cacodylate plus 10 $\mathrm{mM} \mathrm{KCl} / 90 \mathrm{mM} \mathrm{LiCl}, \mathrm{pH} 7.2$, final volume: $100 \mu \mathrm{L} /$ well) with $0.2 \mu \mathrm{M}$ DNA (the labelled sequence F-TWJ-T) and $1 \mu \mathrm{M}$ ligand. The microplate is centrifuged quickly (10 s), gently stirred for $30 \mathrm{~min}$ at $25^{\circ} \mathrm{C}$, centrifuged briefly (10 s) again and then placed into the Mx3005P. After a first equilibration step $\left(25^{\circ} \mathrm{C}, 30 \mathrm{~s}\right)$, a stepwise increase of $1^{\circ} \mathrm{C}$ every $30 \mathrm{~s}$ for 65 cycles to reach $90{ }^{\circ} \mathrm{C}$ was performed, and measurements were made after each cycle. Final data were analysed with Excel and OriginPro ${ }^{\circledR 9}$. The emission of FAM was normalized ( 0 to 1 ), and $T_{1 / 2}$ was defined as the temperature for which the normalized emission is 0.5 ; reported $\Delta T_{1 / 2}$ values are means of 3 experiments. Competitive experiments are performed similarly, that is, with labelled DNA (F-TWJ-T, $0.2 \mu \mathrm{M})$ in presence of ligand (1.0 $\mu \mathrm{M}, 5$ mol. equiv.) and increasing amounts of the unlabelled competitor ds26 $(3.0$ and $10.0 \mu \mathrm{M}, 15$ and $50 \mathrm{~mol}$. equiv.) and TG4T (1.0, 2.0 and $10.0 \mu \mathrm{M}, 5,10$ and 50 mol. equiv.).

Polyacrylamide gel electrophoresis. Non-denaturing polyacrylamide gel electrophoresis (PAGE) was performed according to the protocol described by J. Malina et al. ${ }^{75}$ in $15 \%$ 
polyacrylamide gel (prepared by mixing $6.8 \mathrm{~mL}$ of acrylamide (40\%), $11.2 \mathrm{~mL}$ of TBE buffer, $180 \mu \mathrm{L}$ of APS (10\% w/v) and $18 \mu \mathrm{L}$ of TEMED; 15 min-polymerization). Samples were prepared in $15 \mu \mathrm{L}$ (volume) comprising $15 \mu \mathrm{L}$ DNA or DNA/ligand mixes plus $3 \mu \mathrm{L}$ of DNA loading dye (6x). Each solution was prepared separately: TWJ-S1 alone (6 $\mu \mathrm{M})$, [TWJ-S1+TWJ-S2+TWJ-S3] (or $\mathrm{M})(6 \mu \mathrm{M}),[\mathrm{M}(6 \mu \mathrm{M})+5$ mol. equiv. ligand $(30 \mu \mathrm{M})]$. The solutions were stirred for $1 \mathrm{~h}$ at $25{ }^{\circ} \mathrm{C}$ prior the addition of $3 \mu \mathrm{L}$ of DNA loading dye (6x). These mixes were stirred for $15 \mathrm{~min}$ at $25{ }^{\circ} \mathrm{C}$ (a period during which the gel is stacked at $7 \mathrm{~W}$ (150-180 V, 43-38 mA) in TBE buffer enriched with $100 \mathrm{mM} \mathrm{NaCl}, \mathrm{pH}$ 8.3) prior the loading of $12 \mu \mathrm{L} /$ well of each solution and $1 \mathrm{~h}$ migration at 7W. After the migration, gels were analysed after a post-staining step (SYBR ${ }^{\circledR}$ Gold solution, $1: 10000,60 \mathrm{~min}, 25^{\circ} \mathrm{C}$ under gentle agitation) with a UVP MultiDoc-It ${ }^{\circledR}$ imaging system $\left(\lambda_{\mathrm{ex}}=302 \mathrm{~nm}\right)$.

ESI-MS analysis. Electrospray mass spectrometry experiments were performed on a LTQ Orbitrap XL (Thermo Scientific) spectrometer equipped with Ion Max source and HESI-II probe in the negative ion mode. TWJ alone as well as the corresponding TWJ:ligand mixtures (1:1 mol. equiv.) were prepared in $100 \mathrm{mM}$ ammonium acetate buffer and equilibrated at $25^{\circ} \mathrm{C}$ for $1 \mathrm{~h}$. To obtain a stable electrospray signal, $20 \%$ of methanol were added to the solution just before injection. The solutions were injected with syringe pump at a flow rate of $5 \mu \mathrm{L} / \mathrm{min}$. The full scan mass was recorded in $600-4000 \mathrm{~m} / \mathrm{z}$ range. The following tuning parameters were used: heater temperature $=50^{\circ} \mathrm{C}$, spray voltage $=4.0 \mathrm{kV}$, capillary temperature $=275^{\circ} \mathrm{C}$, Tube lens $=-160.00$ (negative ion mode) and the capillary voltage varied between $-35.00 \mathrm{~V}$ and 60.00 V. Quantification of the equilibrium affinity constants (K) of ligands for TWJ was done according to F. Rosu et al. ${ }^{58}$

Cell Culture. MCF7 (breast adenocarcinoma) cells were routinely cultured in $75 \mathrm{~cm}^{2}$ tissue culture flasks (Nunc) at $37^{\circ} \mathrm{C}$ in a humidified, $5 \% \mathrm{CO}_{2}$ atmosphere in Dulbecco's Modified Eagle Medium (DMEM) supplemented with $10 \%$ foetal bovine serum (FBS, Gibco) and $1 \%$ PenicillinStreptomycin (Pen-Strep, 5.0 u. $\mathrm{mL}^{-1}$ Pen/5.0 $\mu \mathrm{g} \cdot \mathrm{mL}^{-1}$ Strep, Gibco) mixture. Cells were subcultured twice a week using standard protocols.

Cell proliferation SRB assay. The antiproliferative properties of the four ligands were assessed through the sulforhodamine B (SRB) assay, according to V. Vichai \& K. Kirtikara ${ }^{60}$ and P. Skehan et al. ${ }^{95}$ Cells were seeded in a 96-well plate (6000 cells/well) in $160 \mu \mathrm{L}$ of growth medium for $24 \mathrm{~h}$ at $37{ }^{\circ} \mathrm{C}$. Then, $40 \mu \mathrm{L}$ of ligand solution were added to reach the final 
concentration of the ligands between 50 and $0.005 \mu \mathrm{M}$ and incubated for $72 \mathrm{~h}$ at $37^{\circ} \mathrm{C}$. After $72 \mathrm{~h}$, the media was removed and the cells fixed with a solution of trichloroacetic acid $10 \%$ $\left(150 \mu \mathrm{L}, 1 \mathrm{~h}\right.$ at $\left.4^{\circ} \mathrm{C}\right)$. The supernatant was removed, the fixed cells were washed with water and then dried. A solution $100 \mu \mathrm{L}$ of SRB (0.2\% in $1 \%$ acetic acid) was added into each well. After 30 min, the supernatant was removed, the wells were washed 3 times with $150 \mu \mathrm{L}$ of acetic acid (1\%) and dried. After that, $150 \mu \mathrm{L}$ of Tris base $(10 \mathrm{mM})$ were added in each well and the microplate gently stirred for $5 \mathrm{~min}$ at $25{ }^{\circ} \mathrm{C}$. Optical density (OD) values were determined at $530 \mathrm{~nm}$. Final data were analyzed with Excel (Microsoft Corp.) and OriginPro ${ }^{\circledR}$ : the $\mathrm{OD}_{530 \mathrm{~nm}}$ was normalized (from 0 to 100; 0 for ligand-treated wells where absolute cell death was observed and 100 for ligand untreated, SRB-stained cells) and IC $C_{50}$ (defined as the concentration at which $50 \%$ of the cell growth inhibition is reached) determined for a normalized $\mathrm{OD}_{530 \mathrm{~nm}}$ of $50 \%$. Reported $\mathrm{IC}_{50}$ values are means of 3 experiments.

Immunodetection and optical imaging protocols. MCF7 cells were seeded on chambered coverglass ( 24 well-plate) and allowed to recover for $24 \mathrm{~h}$ at $37^{\circ} \mathrm{C}$. Cells were either untreated (control) or incubated with ligands at toxic concentration $\left(1 \mathrm{x}\right.$ or $5 \mathrm{x} I \mathrm{C}_{50}$, determined for $72 \mathrm{~h}$ treatment). After 4 -h incubation at $37{ }^{\circ} \mathrm{C}$, cells were fixed and permeabilized with ice-cold $\mathrm{MeOH}$ for $10 \mathrm{~min}$ at $25^{\circ} \mathrm{C}$, before being incubated with a blocking buffer (1\% BSA in PBS 1x$0.1 \%$ Triton $100 \mathrm{x}$ ) for $20 \mathrm{~min}$ at $25^{\circ} \mathrm{C}$. The blocking buffer was eliminated, and the diluted antibodies were applied. Cells were incubated with $\gamma \mathrm{H} 2 \mathrm{AX}$ antibody $(1 / 100)$ for $2 \mathrm{~h}$ at $25^{\circ} \mathrm{C}$, were rinsed thrice with PBS $1 x-0.2 \%$ Triton $100 x$ (5 min each) and then incubated with the AF647-conjugated secondary antibody $(1 / 500)$ for $45 \mathrm{~min}$ at $25^{\circ} \mathrm{C}$ in a humid light-tight box. Cells were then washed thrice with PBS 1x-0.2\% Triton 100x (5 min each) then counterstained with DAPI $(1 \mu \mathrm{g} / \mathrm{mL})$ and mounted with Fluoromount ${ }^{\mathrm{TM}}$. Confocal imaging was performed using a confocal laser-scanning microscope (Leica TCS SP8) with a $\times 63$ objective lenses, and LASX software (Leica Microsystems CMS GmbH). The samples were excited at $405 \mathrm{~nm}$ (DAPI) and $638 \mathrm{~nm}$ (AF647) and the fluorescence collected at 409-499 nm (DAPI) and 649-775 nm (AF647). Image processing was carried out using LASX software.

Flow cytometry. MCF7 cells were seeded on $75 \mathrm{~cm}^{2}$ flasks at $3 \times 10^{6}$-cell density and grew for $24 \mathrm{~h}$ at $37^{\circ} \mathrm{C}$. Afterwards, cells were either untreated (ctrl) or treated with $1 \mathrm{x}$ or $5 \mathrm{x} I \mathrm{C}_{50}$ of 3,3'-TrisBP, 4,4'-TrisBP, TrisPOB and TrisPSB for 4-h incubation. Cells were then taken off and fixed with a paraformaldehyde solution (1\%) for $15 \mathrm{~min}$ at $0{ }^{\circ} \mathrm{C}$. The fixing solution was eliminated, cells were washed with PBS and ice-cold EtOH was added for the night at $-20^{\circ} \mathrm{C}$. 
Cells were counted and $1 \times 10^{6}$ cells were used for the labelling step. In line with the optical imaging protocols (see above), cells were incubated with $\gamma \mathrm{H} 2 \mathrm{AX}$ antibody $(1 / 100)$ for $2 \mathrm{~h}$ at 25 ${ }^{\circ} \mathrm{C}$, rinsed thrice with PBT (0.5 g BSA $+50 \mathrm{~mL}$ PBS $1 \mathrm{x}-0.2 \%$ Triton 100x) and then incubated with the AF647-conjugated secondary antibody (1/500) for $45 \mathrm{~min}$ before being counterstained with DAPI $(1 \mu \mathrm{g} / \mathrm{mL})$ for $30 \mathrm{~min}$. Stained samples were analysed by flow cytometry with a 3-laser LSRII (Becton Dickinson) using $633 \mathrm{~nm}$ excitation for Alexa647 (670/30 BP filter) and $355 \mathrm{~nm}$ excitation for DAPI (450/50 BP filter). Debris were excluded from the analysis by gating a forward scatter versus side scatter plot. Integrated fluorescence measurements for Alexa647 and DAPI were recorded for $10^{4}$ single non-debris events. Data were plotted using FlowJo software and cell aggregates and false positive were excluded.

Synthetic lethality matrices. The antiproliferative properties of combinations of ligands and DNA repair inhibitors (DNA-PKi, ATMi and RAD51i) were assessed through the sulforhodamine-B (SRB) assay. Cells were seeded in a 96-well plate (6000 cells/well) in $160 \mu \mathrm{L}$ of growth medium for $24 \mathrm{~h}$ at $37^{\circ} \mathrm{C}$ prior to be taken in a combination of serial dilutions from 12 to $0.18 \mu \mathrm{M}$ for NU7441 (DNA-PKi), 30 to $0.47 \mu \mathrm{M}$ for KU55933 (ATMi), 15 to $0.23 \mu \mathrm{M}$ for B02 (RAD51i) and 40 to $0.04 \mu \mathrm{M}$ for ligands (3,3'-TrisBP, 4,4'-TrisBP, TrisPOB and TrisPSB). Cell viability was measured after $72 \mathrm{~h}$ according to the SRB protocol described above. The $\mathrm{IC}_{50}$ values (called Dm, for median-effect dose) ${ }^{68-69}$ were calculated for each inhibitor:ligand ratio (from 24:1 to $0.1875: 1$ ). The IC 50 values of inhibitors and ligands alone (IC $C_{50}$ inhibitor or Dm1, $\mathrm{IC}_{50}$ ligand or Dm2) were determined in control wells (single agent only). The contribution to Dm of each drug in the mixture (Dinhibitor or D1, Dligand or D2) was calculated for each ratio, as follows: at 24:1 inhibitor:ligand ratio, D1 $=[\mathrm{Dm} /(24+1)] \times 24$ and D2 $=[\mathrm{Dm} /(24+1)] \times 1 ;$ at 12:1 inhibitor:ligand ratio, $\mathrm{D} 1=[\mathrm{Dm} /(12+1)] \times 12$ and $\mathrm{D} 2=[\mathrm{Dm} /(12+1)] \times 1$; etc. Then, isobolograms were constructed reporting [D2/Dm2] as a function of [D1/Dm1] for each ratio. The combination index $(\mathrm{Cl}$, with $\mathrm{Cl}<1,=1$ and $>1$ for synergistic, additive and antagonistic effects, respectively) was also calculated for each ratio as follows: $C l=\left(D_{1} / D m 1\right)+\left(D_{2} / D m 2\right)$.

Supporting Information. The Supporting Information is available free of charge on the ACS Publications website: Detailed synthesis of azacryptands (Scheme S1), information about the X-ray crystallographic analysis of TrisPOB (Table S1 and Figure S1), additional competitive FRET-melting results (Figures S2) and CD experiments (Figures S3) along with TWJ-Screen, FRET-melting and ESI-MS investigations performed with RNA TWJ (Figures S4-S6) (PDF). 
Acknowledgments \& funding. This work is supported by the CNRS (S.B., A.G. and D.M.), the European Research Council (H2020-MSCA-IF-2016-750368 for K.D. and D.M.), the INSERM Plan Cancer 2014-2019 (19CP117-00 for S.B. and D.M.) and the Agence Nationale de la Recherche (ANR-17-CE17-0010-01 for P.L., A.G. and D.M. \& ANR-18-CE07-0017-03 for P.L. and D.M.), and is part of the project "Pharmacoimagerie \& agents théranostiques" supported by the Université de Bourgogne and Conseil Régional de Bourgogne (PARI) and the European Union (PO FEDER-FSE Bourgogne 2014/2020 programs). The authors are grateful to Anne Cucchiarini (Institut Curie) for HPLC analyses, Marc Pirrotta (ICMUB) for FRET-melting assays, Anaïs Penning for TWJ-Screen assays, Felix Galan for cell counting, Marie-José Penouilh (PACSMUB) for ESI-MS investigations and both the flow cytometry (INSERM UMR1231, DImaCell) and optical imaging platforms (INRA, AgroSup UMR1347) of the Universite de Bourgogne (supported by Conseil Régional de Bourgogne).

\section{References.}

1. Wang, A. H.-J.; Quigley, G. J.; Kolpak, F. J.; Crawford, J. L.; Van Boom, J. H.; van der Marel, G.; Rich, A., Molecular structure of a left-handed double helical DNA fragment at atomic resolution. Nature 1979, 282 (5740), 680.

2. Rich, A.; Zhang, S., Z-DNA: the long road to biological function. Nat. Rev. Genet. 2003, 4 (7), 566.

3. Ravichandran, S.; Subramani, V. K.; Kim, K. K., Z-DNA in the genome: from structure to disease. Biophys. Rev. 2019, 11 (3), 383-387.

4. Duckett, D. R.; Lilley, D., The three-way DNA junction is a Y-shaped molecule in which there is no helix-helix stacking. EMBO J. 1990, 9 (5), 1659-1664.

5. Seeman, N. C.; Kallenbach, N. R., DNA branched junctions. Annu. Rev. Biophys. Biomol. Struct. 1994, 23 (1), 53-86.

6. Lilley, D. M., Structures of helical junctions in nucleic acids. Q. Rev. Biophys. 2000, 33 (2), 109-159.

7. Felsenfeld, G.; Davies, D. R.; Rich, A., Formation of a three-stranded polynucleotide molecule. J. Am. Chem. Soc. 1957, 79 (8), 2023-2024.

8. Duca, M.; Vekhoff, P.; Oussedik, K.; Halby, L.; Arimondo, P. B., The triple helix: 50 years later, the outcome. Nucleic Acids Res. 2008, 36 (16), 5123.

9. Masukata, H.; Tomizawa, J.-i., A mechanism of formation of a persistent hybrid between elongating RNA and template DNA. Cell 1990, 62 (2), 331-338.

10. Reaban, M. E.; Griffin, J. A., Induction of RNA-stabilized DMA conformers by transcription of an immunoglobulin switch region. Nature 1990, 348 (6299), 342. 
11. Santos-Pereira, J. M.; Aguilera, A., R loops: new modulators of genome dynamics and function. Nat. Rev. Genet. 2015, 16 (10), 583-597.

12. Holliday, R., A mechanism for gene conversion in fungi. Genetics Research 1964, 5 (2), 282-304.

13. Liu, Y.; West, S. C., Happy Hollidays: 40th anniversary of the Holliday junction. Nat. Rev. Mol. Cell Biol. 2004, 5 (11), 937-944.

14. Sen, D.; Gilbert, W., Formation of parallel four-stranded complexes by guanine-rich motifs in DNA and its implications for meiosis. Nature 1988, 334, 364-366.

15. Hänsel-Hertsch, R.; Di Antonio, M.; Balasubramanian, S., DNA G-quadruplexes in the human genome: detection, functions and therapeutic potential. Nat. Rev. Mol. Cell Biol. 2017, 18 (5), 279.

16. Gehring, K.; Leroy, J.-L.; Guéron, M., A tetrameric DNA structure with protonated cytosine-cytosine base pairs. Nature 1993, 363 (6429), 561.

17. Abou Assi, H.; Garavís, M.; González, C.; Damha, M. J., i-Motif DNA: structural features and significance to cell biology. Nucleic Acids Res. 2018, 46 (16), 8038-8056.

18. Biffi, G.; Tannahill, D.; McCafferty, J.; Balasubramanian, S., Quantitative visualization of DNA G-quadruplex structures in human cells. Nat. Chem. 2013, 5 (3), 182-186.

19. Zeraati, M.; Langley, D. B.; Schofield, P.; Moye, A. L.; Rouet, R.; Hughes, W. E.; Bryan, T. M.; Dinger, M. E.; Christ, D., I-motif DNA structures are formed in the nuclei of human cells. Nat. Chem. 2018, 10 (6), 631.

20. Neidle, S., Quadruplex Nucleic Acids as Novel Therapeutic Targets. J. Med. Chem. 2016, 59 (13), 5987-6011.

21. Müller, S.; Rodriguez, R., G-quadruplex interacting small molecules and drugs: from bench toward bedside. Exp. Rev. Clin. Pharmacol. 2014, 7 (5), 663-679.

22. Day, H. A.; Pavlou, P.; Waller, Z. A. E., i-Motif DNA: Structure, stability and targeting with ligands. Bioorg. Med. Chem. 2014, 22 (16), 4407-4418.

23. Debnath, M.; Fatma, K.; Dash, J., Chemical Regulation of DNA i-Motifs for Nanobiotechnology and Therapeutics. Angew. Chem. Int. Ed. 2019, 58 (10), 2942-2957.

24. Wang, G.; Vasquez, K., Effects of replication and transcription on DNA structure-related genetic instability. Genes 2017, 8 (1), 17.

25. Puget, N.; Miller, K.; Legube, G., Non-canonical DNA/RNA structures during Transcription-Coupled Double-Strand Break Repair: Roadblocks or Bona fide repair intermediates? DNA Repair 2019, 102661.

26. Bryan, T. M., Mechanisms of DNA Replication and Repair: Insights from the Study of GQuadruplexes. Molecules 2019, 24 (19), 3439.

27. del Mundo, I. M.; Vasquez, K. M.; Wang, G., Modulation of DNA structure formation using small molecules. Biochim. Biophys. Acta-Mol. Cell Res. 2019, 118539.

28. Mirkin, E. V.; Mirkin, S. M., Replication fork stalling at natural impediments. Microbiol. Mol. Biol. Rev. 2007, 71 (1), 13-35. 
29. Belotserkovskii, B. P.; Mirkin, S. M.; Hanawalt, P. C., DNA Sequences That Interfere with Transcription: Implications for Genome Function and Stability. Chem. Rev. 2013, 113 (11), 8620-8637.

30. Weitzmann, M. N.; Woodford, K. J.; Usdin, K., The development and use of a DNA polymerase arrest assay for the evaluation of parameters affecting intrastrand tetraplex formation. J. Biol. Chem. 1996, 271 (34), 20958-20964.

31. Tauchi, T.; Shin-ya, K.; Sashida, G.; Sumi, M.; Nakajima, A.; Shimamoto, T.; Ohyashiki, J. H.; Ohyashiki, K., Activity of a novel G-quadruplex-interactive telomerase inhibitor, telomestatin (SOT-095), against human leukemia cells: involvement of ATM-dependent DNA damage response pathways. Oncogene 2003, 22 (34), 5338-5347.

32. Gomez, D.; Wenner, T.; Brassart, B.; Douarre, C.; O'Donohue, M.-F.; El Khoury, V.; Shinya, K.; Morjani, H.; Trentesaux, C.; Riou, J.-F., Telomestatin-induced telomere uncapping is modulated by POT1 through G-overhang extension in HT1080 human tumor cells. J. Biol. Chem. 2006, 281 (50), 38721-38729.

33. Rizzo, A.; Salvati, E.; Porru, M.; D'Angelo, C.; Stevens, M. F.; D'Incalci, M.; Leonetti, C.; Gilson, E.; Zupi, G.; Biroccio, A., Stabilization of quadruplex DNA perturbs telomere replication leading to the activation of an ATR-dependent ATM signaling pathway. Nucleic Acids Res. 2009, 37 (16), 5353-5364.

34. Biroccio, A.; Porru, M.; Rizzo, A.; Salvati, E.; D'Angelo, C.; Orlandi, A.; Passeri, D.; Franceschin, M.; Stevens, M. F.; Gilson, E., DNA damage persistence as determinant of tumor sensitivity to the combination of Topo I inhibitors and telomere-targeting agents. Clin. Cancer Res. 2011, 17 (8), 2227-2236.

35. Gauthier, L. R.; Granotier, C.; Hoffschir, F.; Etienne, O.; Ayouaz, A.; Desmaze, C.; Mailliet, P.; Biard, D. S.; Boussin, F. D., Rad51 and DNA-PKcs are involved in the generation of specific telomere aberrations induced by the quadruplex ligand 360A that impair mitotic cell progression and lead to cell death. Cell. Mol. Life Sci. 2012, 69 (4), 629-640.

36. Rodriguez, R.; Miller, K. M.; Forment, J. V.; Bradshaw, C. R.; Nikan, M.; Britton, S.; Oelschlaegel, T.; Xhemalce, B.; Balasubramanian, S.; Jackson, S. P., Small-moleculeinduced DNA damage identifies alternative DNA structures in human genes. Nat. Chem. Biol. 2012, 8 (3), 301-310.

37. Zimmer, J.; Tacconi, E. M.; Folio, C.; Badie, S.; Porru, M.; Klare, K.; Tumiati, M.; Markkanen, E.; Halder, S.; Ryan, A., Targeting BRCA1 and BRCA2 deficiencies with Gquadruplex-interacting compounds. Mol. Cell 2016, 61 (3), 449-460.

38. De Magis, A.; Manzo, S. G.; Russo, M.; Marinello, J.; Morigi, R.; Sordet, O.; Capranico, G., DNA damage and genome instability by $\mathrm{G}$-quadruplex ligands are mediated by $\mathrm{R}$ loops in human cancer cells. Proc. Natl. Acad. Sci. U. S. A. 2019, 116 (3), 816-825.

39. Xu, H.; Di Antonio, M.; McKinney, S.; Mathew, V.; Ho, B.; O’Neil, N. J.; Dos Santos, N.; Silvester, J.; Wei, V.; Garcia, J., CX-5461 is a DNA G-quadruplex stabilizer with selective lethality in BRCA1/2 deficient tumours. Nat. Commun. 2017, 8, 14432.

40. Hotze, A. C.; Hodges, N. J.; Hayden, R. E.; Sanchez-Cano, C.; Paines, C.; Male, N.; Tse, M.K.; Bunce, C. M.; Chipman, J. K.; Hannon, M. J., Supramolecular iron cylinder with unprecedented DNA binding is a potent cytostatic and apoptotic agent without exhibiting genotoxicity. Chem. Biol. 2008, 15 (12), 1258-1267. 
41. Guyon, L.; Pirrotta, M.; Duskova, K.; Granzhan, A.; Teulade-Fichou, M.-P.; Monchaud, D., TWJ-Screen: an isothermal screening assay to assess ligand/DNA junction interactions in vitro. Nucleic Acids Res. 2018, 46 (3), e16.

42. Duskova, K.; Lamarche, J.; Amor, S.; Caron, C.; Queyriaux, N.; Gaschard, M.; Penouilh, M.-J.; de Robillard, G.; Delmas, D.; Devillers, C. H.; Granzhan, A.; Teulade-Fichou, M.-P.; Chavarot-Kerlidou, M.; Therrien, B.; Britton, S.; Monchaud, D., Identification of ThreeWay DNA Junction Ligands through Screening of Chemical Libraries and Validation by Complementary in Vitro Assays. J. Med. Chem. 2019, 62 (9), 4456-4466.

43. Novotna, J.; Laguerre, A.; Granzhan, A.; Pirrotta, M.; Teulade-Fichou, M.-P.; Monchaud, D., Cationic azacryptands as selective three-way DNA junction binding agents. Org. Biomol. Chem. 2015, 13 (1), 215-222.

44. Oleksi, A.; Blanco, A. G.; Boer, R.; Usón, I.; Aymamí, J.; Rodger, A.; Hannon, M. J.; Coll, M., Molecular Recognition of a Three-Way DNA Junction by a Metallosupramolecular Helicate. Angew. Chem. Int. Ed. 2006, 45 (8), 1227-1231.

45. Cardo, L.; Hannon, M. J., Non-covalent Metallo-Drugs: Using Shape to Target DNA and RNA Junctions and Other Nucleic Acid Structures. Metallo-Drugs: Development and Action of Anticancer Agents 2018, 18, 303.

46. Kaelin, W. G., The concept of synthetic lethality in the context of anticancer therapy. Nat. Rev. Cancer 2005, 5 (9), 689-698.

47. McLuckie, K. I. E.; Di Antonio, M.; Zecchini, H.; Xian, J.; Caldas, C.; Krippendorff, B. F.; Tannahill, D.; Lowe, C.; Balasubramanian, S., G-Quadruplex DNA as a Molecular Target for Induced Synthetic Lethality in Cancer Cells. J. Am. Chem. Soc. 2013, 135 (26), 96409643.

48. Zyner, K. G.; Mulhearn, D. S.; Adhikari, S.; Cuesta, S. M.; Di Antonio, M.; Erard, N.; Hannon, G. J.; Tannahill, D.; Balasubramanian, S., Genetic interactions of Gquadruplexes in humans. elife 2019, 8, e46793.

49. Boiocchi, M.; Bonizzoni, M.; Fabbrizzi, L.; Piovani, G.; Taglietti, A., A dimetallic cage with a long ellipsoidal cavity for the fluorescent detection of dicarboxylate anions in water. Angew. Chem. Int. Ed. 2004, 43 (29), 3847-3852.

50. Kołodziejski, M.; Stefankiewicz, A. R.; Lehn, J.-M., Dynamic polyimine macrobicyclic cryptands - self-sorting with component selection. Chem. Sci. 2019, 10 (6), 1836-1843.

51. Amendola, V.; Alberti, G.; Bergamaschi, G.; Biesuz, R.; Boiocchi, M.; Ferrito, S.; Schmidtchen, F. P., Cavity effect on perrhenate recognition by polyammonium cages. Eur. J. Inorg. Chem. 2012, 2012 (21), 3410-3417.

52. Alibrandi, G.; Amendola, V.; Bergamaschi, G.; Fabbrizzi, L.; Licchelli, M., Bistren cryptands and cryptates: versatile receptors for anion inclusion and recognition in water. Org. Biomol. Chem. 2015, 13 (12), 3510-3524.

53. Kadrmas, J. L.; Ravin, A. J.; Leontis, N. B., Relative stabilities of DNA three-way, four-way and five-way junctions (multi-helix junction loops): unpaired nucleotides can be stabilizing or destabilizing. Nucleic Acids Res. 1995, 23 (12), 2212-2222.

54. Stefan, L.; Bertrand, B.; Richard, P.; Le Gendre, P.; Denat, F.; Picquet, M.; Monchaud, D., Assessing the Differential Affinity of Small Molecules for Noncanonical DNA Structures. ChemBioChem 2012, 13 (13), 1905-1912. 
55. Vuong, S.; Stefan, L.; Lejault, P.; Rousselin, Y.; Denat, F.; Monchaud, D., Identifying threeway DNA junction-specific small-molecules. Biochimie 2012, 94 (2), 442-450.

56. De Cian, A.; Guittat, L.; Kaiser, M.; Sacca, B.; Amrane, S.; Bourdoncle, A.; Alberti, P.; Teulade-Fichou, M.-P.; Lacroix, L.; Mergny, J.-L., Fluorescence-based melting assays for studying quadruplex ligands. Methods 2007, 42 (2), 183-195.

57. Haudecoeur, R.; Stefan, L.; Monchaud, D., Multitasking Water-Soluble Synthetic GQuartets: From Preferential RNA-Quadruplex Interaction to Biocatalytic Activity. Chem. Eur. J. 2013, 19 (38), 12739-12747.

58. Rosu, F.; Gabelica, V.; Houssier, C.; De Pauw, E., Determination of affinity, stoichiometry and sequence selectivity of minor groove binder complexes with double-stranded oligodeoxynucleotides by electrospray ionization mass spectrometry. Nucleic Acids Res. 2002, 30 (16), e82-e82.

59. Rosu, F.; De Pauw, E.; Gabelica, V., Electrospray mass spectrometry to study drug-nucleic acids interactions. Biochimie 2008, 90 (7), 1074-1087.

60. Vichai, V.; Kirtikara, K., Sulforhodamine B colorimetric assay for cytotoxicity screening. Nat. Protoc. 2006, 1 (3), 1112.

61. Bonner, W. M.; Redon, C. E.; Dickey, J. S.; Nakamura, A. J.; Sedelnikova, O. A.; Solier, S.; Pommier, Y., yH2AX and cancer. Nat. Rev. Cancer 2008, 8 (12), 957-967.

62. Blackford, A. N.; Jackson, S. P., ATM, ATR, and DNA-PK: The Trinity at the Heart of the DNA Damage Response. Mol. Cell 2017, 66 (6), 801-817.

63. Ciccia, A.; Elledge, S. J., The DNA damage response: making it safe to play with knives. Mol. Cell 2010, 40 (2), 179-204.

64. Leahy, J. J.; Golding, B. T.; Griffin, R. J.; Hardcastle, I. R.; Richardson, C.; Rigoreau, L.; Smith, G. C., Identification of a highly potent and selective DNA-dependent protein kinase (DNA-PK) inhibitor (NU7441) by screening of chromenone libraries. Bioorg. Med. Chem. Lett. 2004, 14 (24), 6083-6087.

65. Hickson, I.; Zhao, Y.; Richardson, C. J.; Green, S. J.; Martin, N. M.; Orr, A. I.; Reaper, P. M.; Jackson, S. P.; Curtin, N. J.; Smith, G. C., Identification and characterization of a novel and specific inhibitor of the ataxia-telangiectasia mutated kinase ATM. Cancer Res. 2004, 64 (24), 9152-9159.

66. Huang, F.; Motlekar, N. A.; Burgwin, C. M.; Napper, A. D.; Diamond, S. L.; Mazin, A. V., Identification of specific inhibitors of human RAD51 recombinase using high-throughput screening. ACS Chem. Biol. 2011, 6 (6), 628-635.

67. Karanam, K.; Kafri, R.; Loewer, A.; Lahav, G., Quantitative live cell imaging reveals a gradual shift between DNA repair mechanisms and a maximal use of HR in mid S phase. Mol. Cell 2012, 47 (2), 320-329.

68. Chou, T.-C., Theoretical basis, experimental design, and computerized simulation of synergism and antagonism in drug combination studies. Pharmacol. Rev. 2006, 58 (3), 621-681.

69. Chou, T.-C.; Talalay, P., Analysis of combined drug effects: a new look at a very old problem. Trends Pharmacol. Sci. 1983, 4, 450-454. 
70. Prichard, M. N.; Shipman Jr, C., A three-dimensional model to analyze drug-drug interactions. Antiviral Res. 1990, 14 (4-5), 181-205.

71. Guo, Q.; Seeman, N. C.; Kallenbach, N. R., Site-specific interaction of intercalating drugs with a branched DNA molecule. Biochemistry 1989, 28 (6), 2355-2359.

72. Lu, M.; Guo, Q.; Pasternack, R. F.; Wink, D. J.; Seeman, N. C.; Kallenbach, N. R., Drug binding by branched DNA: selective interaction of tetrapyridyl porphyrins with an immobile junction. Biochemistry 1990, 29 (6), 1614-1624.

73. Lu, M.; Guo, Q.; Kallenbach, N. R., Interaction of drugs with branched DNA structures. Crit. Rev. Biochem. Mol. Biol. 1992, 27 (3), 157-190.

74. Cerasino, L.; Hannon, M. J.; Sletten, E., DNA three-way junction with a dinuclear iron (II) supramolecular helicate at the center: A NMR structural study. Inorg. Chem. 2007, 46 (16), 6245-6251.

75. Malina, J.; Hannon, M. J.; Brabec, V., Recognition of DNA Three-Way Junctions by Metallosupramolecular Cylinders: Gel Electrophoresis Studies. Chem. Eur. J. 2007, 13 (14), 3871-3877.

76. Lejault, P.; Duskova, K.; Bernhard, C.; Valverde, I. E.; Romieu, A.; Monchaud, D., The scope of application of macrocyclic polyamines beyond metal chelation. Eur. J. Org. Chem. 2019, 2019 (36), 6146-6157.

77. Barros, S. A.; Chenoweth, D. M., Recognition of Nucleic Acid Junctions Using TriptyceneBased Molecules. Angew. Chem. Int. Ed. 2014, 53 (50), 13746-13750.

78. Barros, S. A.; Chenoweth, D. M., Triptycene-based small molecules modulate (CAG).(CTG) repeat junctions. Chem. Sci. 2015, 6 (8), 4752-4755.

79. Yang, Z.; Chen, Y.; Li, G.; Tian, Z.; Zhao, L.; Wu, X.; Ma, Q.; Liu, M.; Yang, P., Supramolecular Recognition of Three Way Junctions DNA by a Cationic Calix [3] carbazole. Chem. Eur. J. 2018, 24, 6087-6093.

80. Wan, Y.; Kertesz, M.; Spitale, R. C.; Segal, E.; Chang, H., Understanding the transcriptome through RNA structure. Nat. Rev. Genet. 2011, 12 (9), 641-655.

81. Mortimer, S. A.; Kidwell, M. A.; Doudna, J. A., Insights into RNA structure and function from genome-wide studies. Nat. Rev. Genet. 2014, 15, 469.

82. Kwok, C. K.; Tang, Y.; Assmann, S. M.; Bevilacqua, P. C., The RNA structurome: transcriptome-wide structure probing with next-generation sequencing. Trends Biochem. Sci. 2015, 40 (4), 221-232.

83. Ganser, L. R.; Kelly, M. L.; Herschlag, D.; Al-Hashimi, H. M., The roles of structural dynamics in the cellular functions of RNAs. Nat. Rev. Mol. Cell Biol. 2019, 1.

84. Phongtongpasuk, S.; Paulus, S.; Schnabl, J.; Sigel, R. K.; Spingler, B.; Hannon, M. J.; Freisinger, E., Binding of a Designed Anti-Cancer Drug to the Central Cavity of an RNA Three-Way Junction. Angew. Chem. Int. Ed. 2013, 52 (44), 11513-11516.

85. Ducani, C.; Leczkowska, A.; Hodges, N. J.; Hannon, M. J., Noncovalent DNA-Binding Metallo-Supramolecular Cylinders Prevent DNA Transactions in vitro. Angew. Chem. Int. Ed. 2010, 49 (47), 8942-8945.

86. Scully, R.; Panday, A.; Elango, R.; Willis, N. A., DNA double-strand break repair-pathway choice in somatic mammalian cells. Nat. Rev. Mol. Cell Biol. 2019, 20 (11), 698-714. 
87. Wang, C.; Jette, N.; Moussienko, D.; Bebb, D. G.; Lees-Miller, S. P., ATM-deficient colorectal cancer cells are sensitive to the PARP inhibitor olaparib. Transl. Oncol. 2017, $10(2), 190-196$.

88. Kubota, E.; Williamson, C. T.; Ye, R.; Elegbede, A.; Peterson, L.; Lees-Miller, S. P.; Bebb, D. G., Low ATM protein expression and depletion of p53 correlates with olaparib sensitivity in gastric cancer cell lines. Cell Cycle 2014, 13 (13), 2129-2137.

89. Kotera, N.; Poyer, F.; Granzhan, A.; Teulade-Fichou, M.-P., Efficient inhibition of human AP endonuclease 1 (APE1) via substrate masking by abasic site-binding macrocyclic ligands. Chem. Commun. 2015, 51 (88), 15948-15951.

90. Caron, C.; Duong, X. N.; Guillot, R.; Bombard, S.; Granzhan, A., Interaction of functionalized naphthalenophanes with abasic sites in DNA: DNA cleavage, DNA cleavage inhibition, and formation of ligand-DNA adducts. Chem. Eur. J. 2019, 25 (8), 1949-1962.

91. Taniguchi, N., Diarylation of chalcogen elements using arylboronic acids via copper-or palladium-catalyzed oxidative coupling. Tetrahedron 2016, 72 (38), 5818-5823.

92. Sheldrick, G. M., SHELXS-97, Program for crystal structure solution. University of Göttingen, Germany Göttingen: 1997.

93. Sheldrick, G. M., A short history of SHELX. Acta Crystallogr., Sect. A: Found. Crystallogr. 2008, 64 (1), 112-122.

94. Farrugia, L. J., WinGX suite for small-molecule single-crystal crystallography. J. Appl. Crystallogr. 1999, 32 (4), 837-838.

95. Skehan, P.; Storeng, R.; Scudiero, D.; Monks, A.; McMahon, J.; Vistica, D.; Warren, J. T.; Bokesch, H.; Kenney, S.; Boyd, M. R., New colorimetric cytotoxicity assay for anticancerdrug screening. J. Natl. Cancer Inst. 1990, 82 (13), 1107-1112.

Graphical abstract for Table of Contents (TOC)

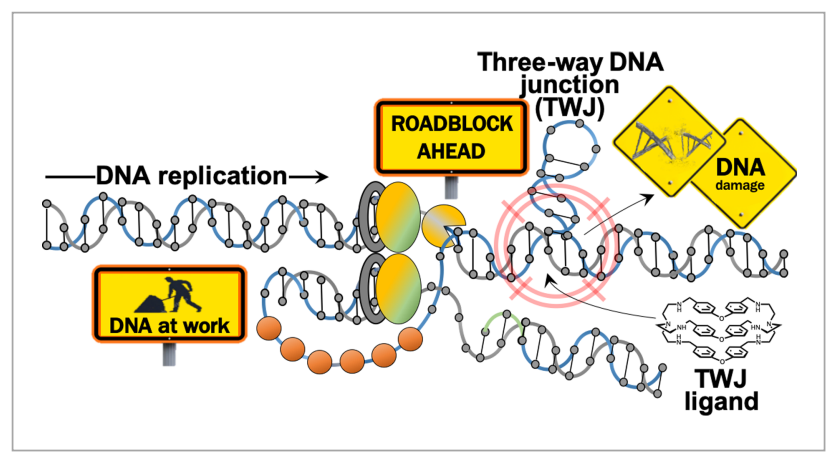




\title{
DNA junction ligands trigger DNA damage and are synthetic lethal with DNA repair inhibitors in cancer cells
}

\author{
Katerina Duskova, ${ }^{1}$ Pauline Lejault, ${ }^{1}$ Élie Benchimol, ${ }^{2,3}$ Régis Guillot, ${ }^{4}$ \\ Sébastien Britton, ${ }^{5, \star}$ Anton Granzhan ${ }^{2,3, \star}$ and David Monchaud ${ }^{1, \star}$
}

\begin{abstract}
${ }^{1}$ Institut de Chimie Moléculaire de l'Université de Bourgogne (ICMUB), CNRS UMR 6302, UBFC Dijon, 21078 Dijon, France; ^david.monchaud@cnrs.fr. ${ }^{2}$ Institut Curie, CNRS UMR 9187, INSERM U1196, PSL Research University, 91405 Orsay, France. ${ }^{3}$ Université Paris-Sud, Université Paris Saclay, CNRS UMR 9187, INSERM U1196, 91405 Orsay, France; ${ }^{\star}$ anton.granzhan@curie.fr. ${ }^{4}$ Institut de Chimie Moléculaire et des Matériaux d'Orsay (ICMMO), CNRS UMR 8182, Université Paris-Sud, Université Paris Saclay, 91405 Orsay, France. ${ }^{5}$ Institut de Pharmacologie et de Biologie Structurale (IPBS), CNRS UMR 5089, Université de Toulouse, UPS, Equipe labellisée la Ligue Contre le Cancer, 31077 Toulouse, France; `sebastien.britton@ipbs.fr
\end{abstract}

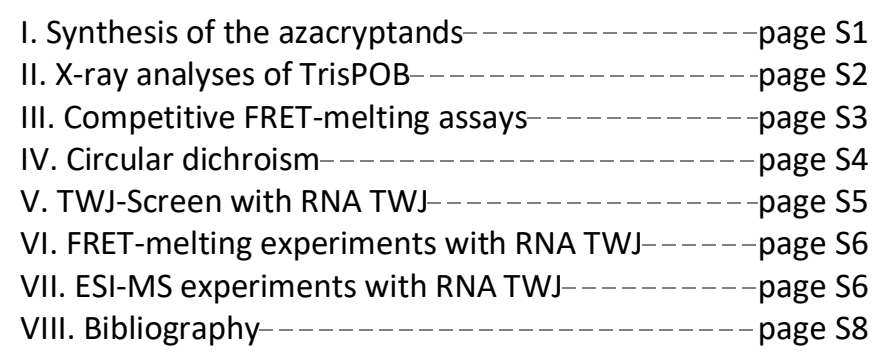

\section{Synthesis of azacryptands}

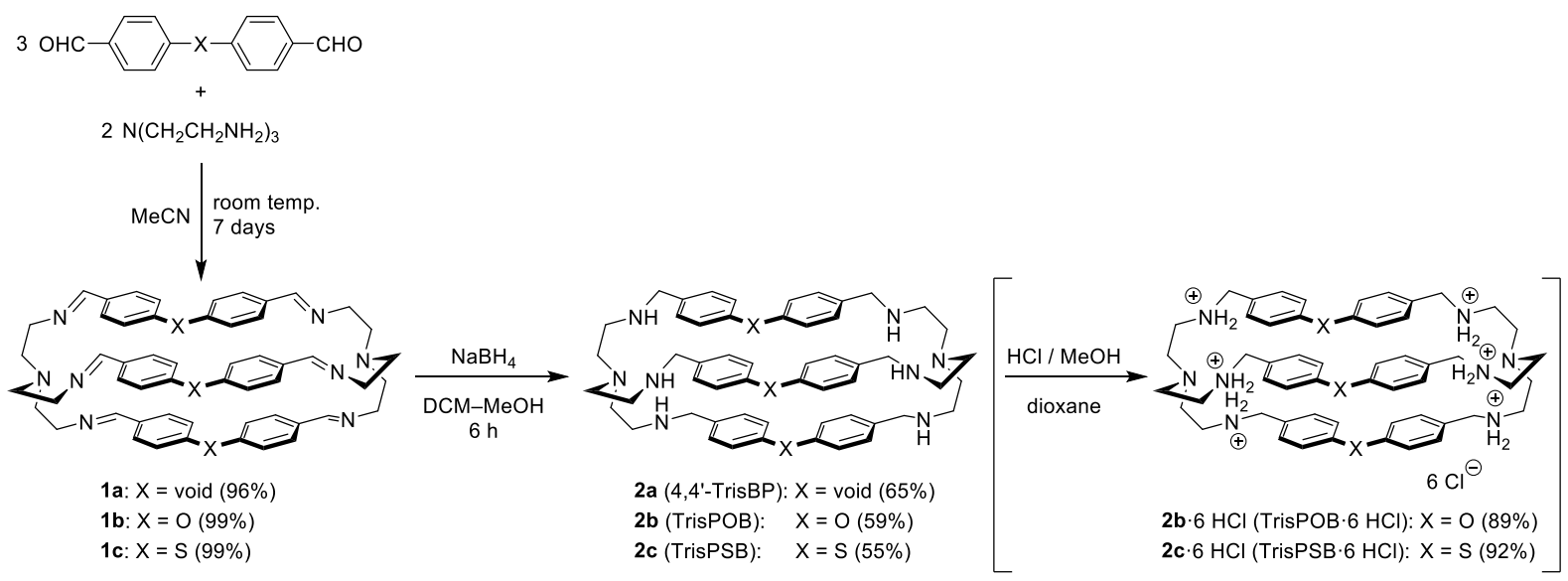

Scheme S1. Synthesis of azacryptands. 


\section{X-ray crystallographic data}

Table S1. Crystallographic data and structure refinement details for TrisPOB $\times 6 \mathrm{HCl}$

\begin{tabular}{|c|c|}
\hline Compound & TrisPOB $\times 6 \mathrm{HCl}$ \\
\hline Empirical formula & $\mathrm{C}_{54} \mathrm{H}_{72} \mathrm{~N}_{8} \mathrm{O}_{3}, 2(\mathrm{CO}), 6(\mathrm{Cl}), 8.5(\mathrm{O})$ \\
\hline$M_{r}$ & 1301.91 \\
\hline Crystal size, $\mathrm{mm}^{3}$ & $0.10 \times 0.04 \times 0.03$ \\
\hline Crystal system & triclinic \\
\hline Space group & $\overline{P 1}$ \\
\hline a, $\AA$ & $12.7575(4)$ \\
\hline$b, \AA$ & $14.9861(4)$ \\
\hline$c, \AA$ & $18.7654(5)$ \\
\hline$\alpha,{ }^{\circ}$ & $75.095(2)$ \\
\hline$\beta$, & $85.008(2)$ \\
\hline$\gamma^{\circ}$ & $81.644(2)$ \\
\hline Cell volume, $\AA^{3}$ & $3425.52(17)$ \\
\hline$T, \mathrm{~K}$ & $100(1)$ \\
\hline Radiation type ; wavelength, $\AA$ & $\mathrm{Cu} \mathrm{K \alpha} ; 1.54178$ \\
\hline$F_{000}$ & 1364 \\
\hline$\mu, \mathrm{mm}^{-1}$ & 2.773 \\
\hline$\theta$ range $^{\circ}$ & $3.077-70.224$ \\
\hline Reflection collected & 106001 \\
\hline Reflections unique & 12992 \\
\hline$R_{\text {int }}$ & 0.0395 \\
\hline GOF & 1.032 \\
\hline Refl. obs. $(I>2 \sigma(I))$ & 10202 \\
\hline Parameters & 820 \\
\hline$w R_{2}$ (all data) & 0.2529 \\
\hline$R$ value $(I>2 \sigma(I))$ & 0.0837 \\
\hline Largest diff. peak and hole $\left(\mathrm{e}^{-} . \AA^{-3}\right)$ & $2.448 ;-0.925$ \\
\hline
\end{tabular}



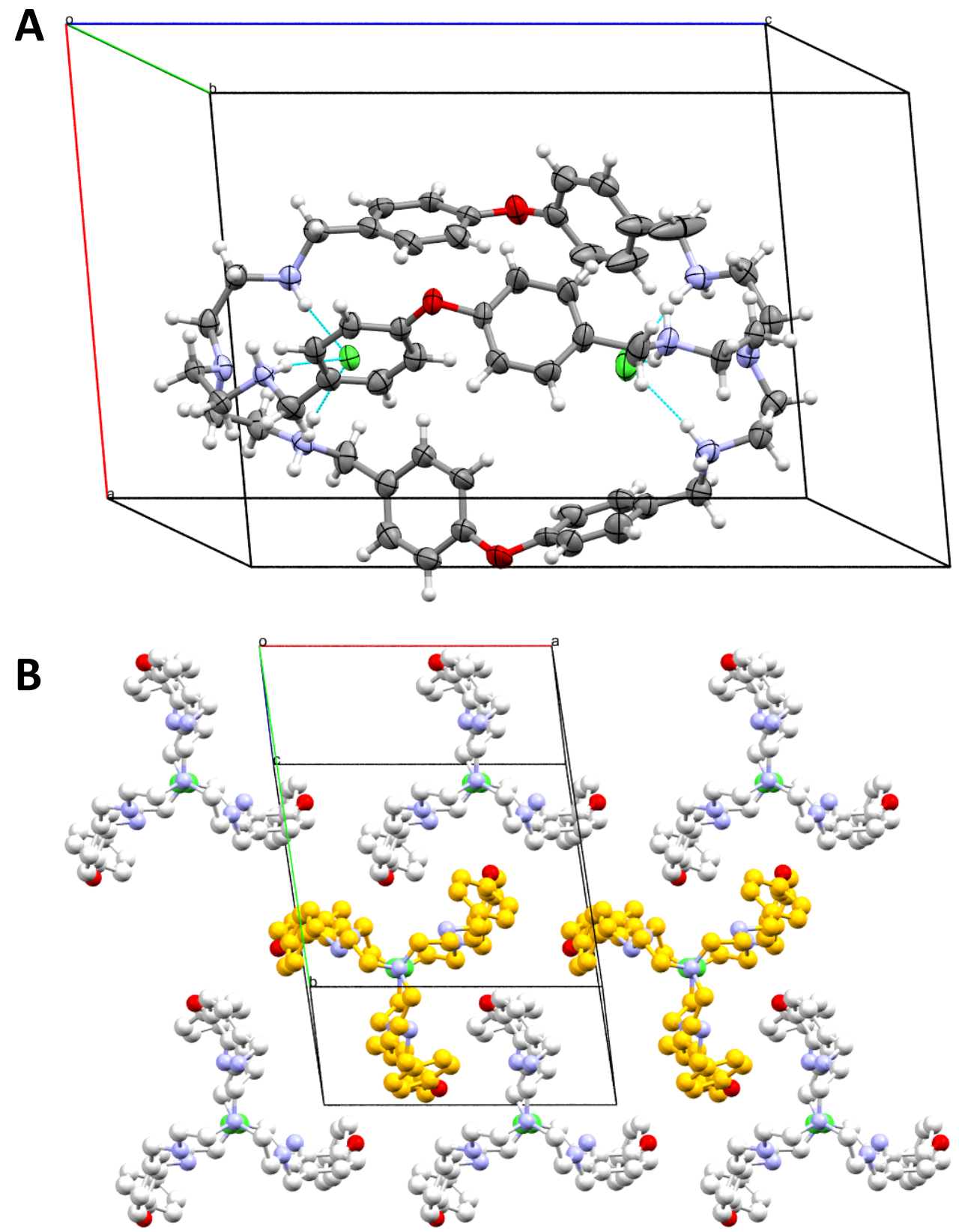

Figure S1. A) ORTEP plot of TrisPOB $\times 6 \mathrm{HCl}$ from single-crystal X-ray diffraction analysis. Thermal ellipsoids for non-hydrogen atoms are drawn at the $70 \%$ probability level; cyan lines: intramolecular hydrogen bonds. Non-bound counterions and solvent molecules are omitted for the sake of clarity. B) Crystal packing of TrisPOB $\times 6 \mathrm{HCl}$, viewed along the pseudo- $\mathrm{C}_{3}$ molecular axis. Molecules are colored by symmetry operation.

\section{Competitive FRET-melting assays}

According to the original report, ${ }^{1}$ the competitive FRET-melting assay must be performed with highly stable unlabeled competitors, i.e., competitors displaying a melting temperature at least $>20^{\circ} \mathrm{C}$ above that of the doubly labeled oligonucleotide, here F-TWJ-T. We thus employed both the unlabeled duplex-DNA ds26 (the self-complementary sequence $\mathrm{d}\left[{ }^{5^{\prime}} \mathrm{CA}_{2} \mathrm{TCG}_{2} \mathrm{ATCGA}_{2} \mathrm{~T}_{2} \mathrm{CGATC}_{2} \mathrm{GAT}_{2} \mathrm{G}^{3}\right], \mathrm{T}_{\mathrm{m}}=70.5^{\circ} \mathrm{C}^{1}{ }^{1}$ Figure $\left.2 \mathrm{E}\right)$ and the unlabeled quadruplex- 


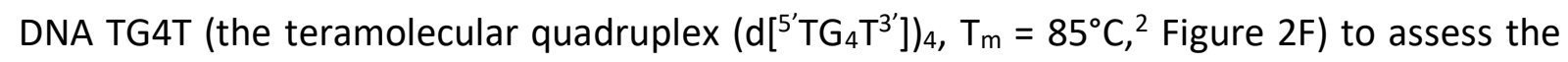
TWJ-selectivity of the azacryptands. The possibility of using a less stable, intramolecular quadruplex competitor was also discussed in the literature, ${ }^{3}$ as a way to assess the possible influence of the quadruplex loops. We thus used 22AG (aka H-Telo, ${ }^{3} d\left[{ }^{5} A G_{3}\left(T_{2} A G_{2}\right)_{3}{ }^{{ }^{\prime}}\right], T_{m}=$ $63^{\circ} \mathrm{C},{ }^{4}$ Figure S2) as competitor: results show that a stable (tetramolecular) quadruplex competitor provides a fiercer competition that a less stable (intramolecular) quadruplex competitor, with FRET-melting selectivity values ( ${ }^{\text {FRETS }}$, defined as ${ }^{\text {FRETS }}=\Delta T_{1 / 2[\text { with }}$

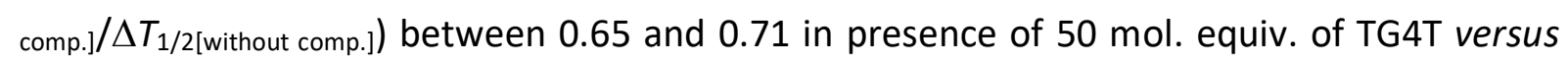
between 0.78 and 0.94 in presence of 50 mol. equiv. of $22 \mathrm{AG}$.
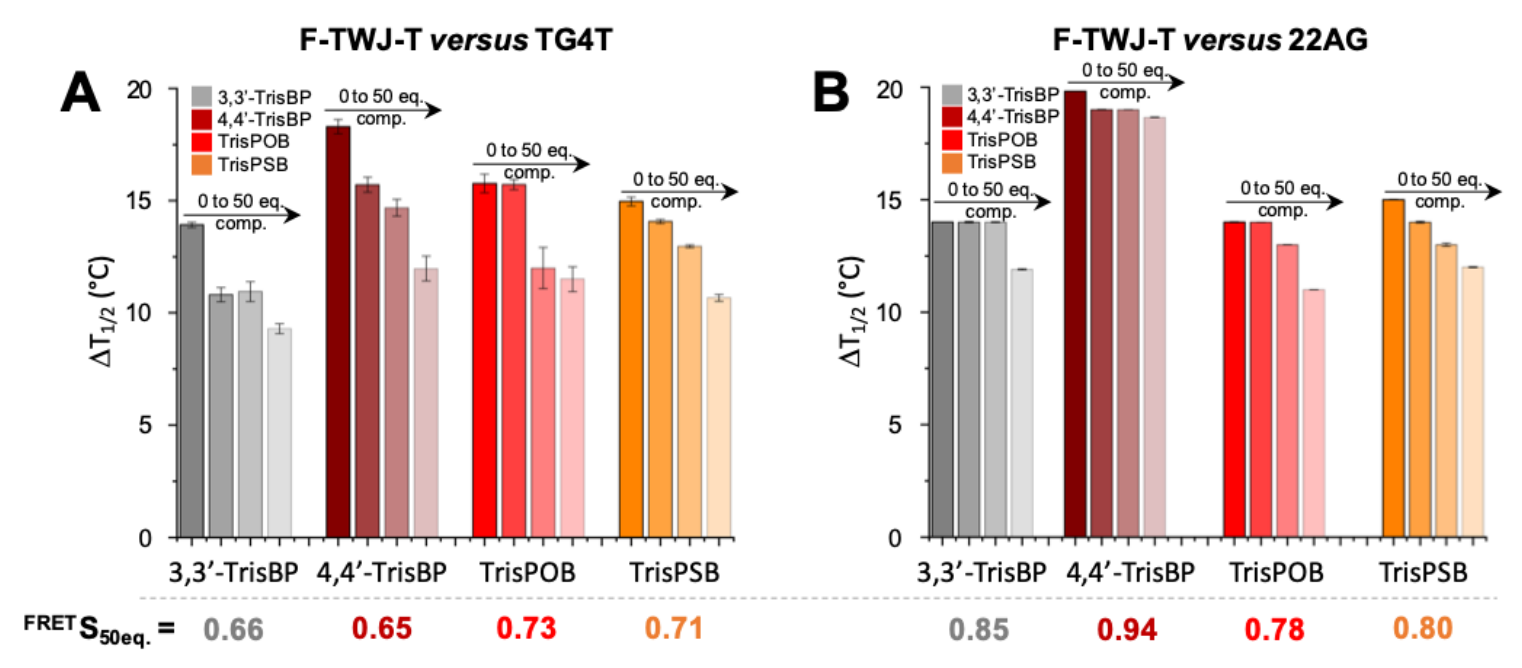

Figure S2. Competitive FRET-melting experiment performed with F-TWJ-T $(0.2 \mu \mathrm{M})$ in presence of 3,3'TrisBP, 4, $4^{\prime}-$ TrisBP, TrisPOB and TrisPSB $(1.0 \mu \mathrm{M})$ and increasing concentrations $(0,1.0,2.0$ and $10.0 \mu \mathrm{M})$ of the tetramolecular quadruplex TG4T (A) or the intramolecular quadruplex 22AG (B).

\section{Circular dichroism assessment of the competitors' topology}

The topology of the higher-order DNA structures used in the competitive FRET-melting assays was confirmed by circular dichroism (CD) investigations. CD spectra were recorded on a JASCO $\mathrm{J}-815$ spectropolarimeter in a $10 \mathrm{~mm}$ path-length quartz semi-micro cuvette, over a range of 220-400 nm (bandwidth $=0.5 \mathrm{~nm}, 1 \mathrm{~nm}$ pitch, 1s response, scan speed $=500 \mathrm{~nm} \cdot \mathrm{mn}-1$, averaged over 3 scans, zeroed at $340 \mathrm{~nm}$ ) with $3 \mu \mathrm{M}$ DNA in $10 \mathrm{mM}$ lithium cacodylate buffer $(\mathrm{pH} 7.2)+90 \mathrm{mM} \mathrm{LiCl} / 10 \mathrm{mM} \mathrm{KCl}$. The profiles obtained (Figure S3) are in agreement with those previously reported that can be found in Ref. ${ }^{5}$ for $22 \mathrm{AG}$, Ref. ${ }^{6}$ for TG4T, Ref. ${ }^{7}$ for ds 26 and Ref. ${ }^{8}$ for TWJ. 


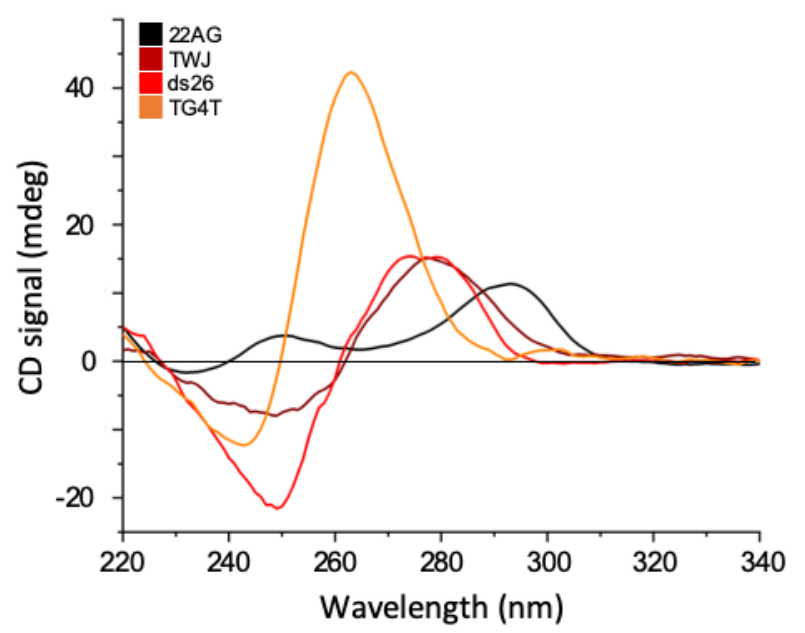

Figure S3. CD profiles of quadruplex-DNA (22AG and TG4T), duplex-DNA (ds26) and TWJ.

\section{TWJ-Screen with RNA TWJ}

The TWJ-screen assay ${ }^{9}$ was performed with DNA strands but can be adapted to RNA as well. To this end, a mixture $(M)$ of the three RNA TWJ-forming strands, i.e., FAM-TWJ-RNA-S 1 (FAM$\left.r\left[{ }^{5^{\prime}} \mathrm{CG}_{2} \mathrm{~A}_{2} \mathrm{CG}_{2} \mathrm{CACUCG}^{3}\right]\right)$, TWJ-RNA-S $\left(r{ }^{\left.\left.5^{\prime} C G A G U G C A G C G U G_{2}{ }^{3}\right]\right)}\right.$ and TWJ-RNA-S - TAMRA ( $r\left[{ }^{5^{\prime}} \mathrm{C}_{2} \mathrm{ACGCUCGU}{ }_{2} \mathrm{C}_{2} \mathrm{G}^{\prime}\right]$-TAMRA) was stirred at $37^{\circ} \mathrm{C}$ for $1 \mathrm{~h}$ without (control, along with FAMTWJ-S $S_{1}$ alone to define the $100 \%$ FAM emission) or with 5 molar equivalents (mol. equiv., 1.0 $\mu \mathrm{M})$ of the azacryptands.
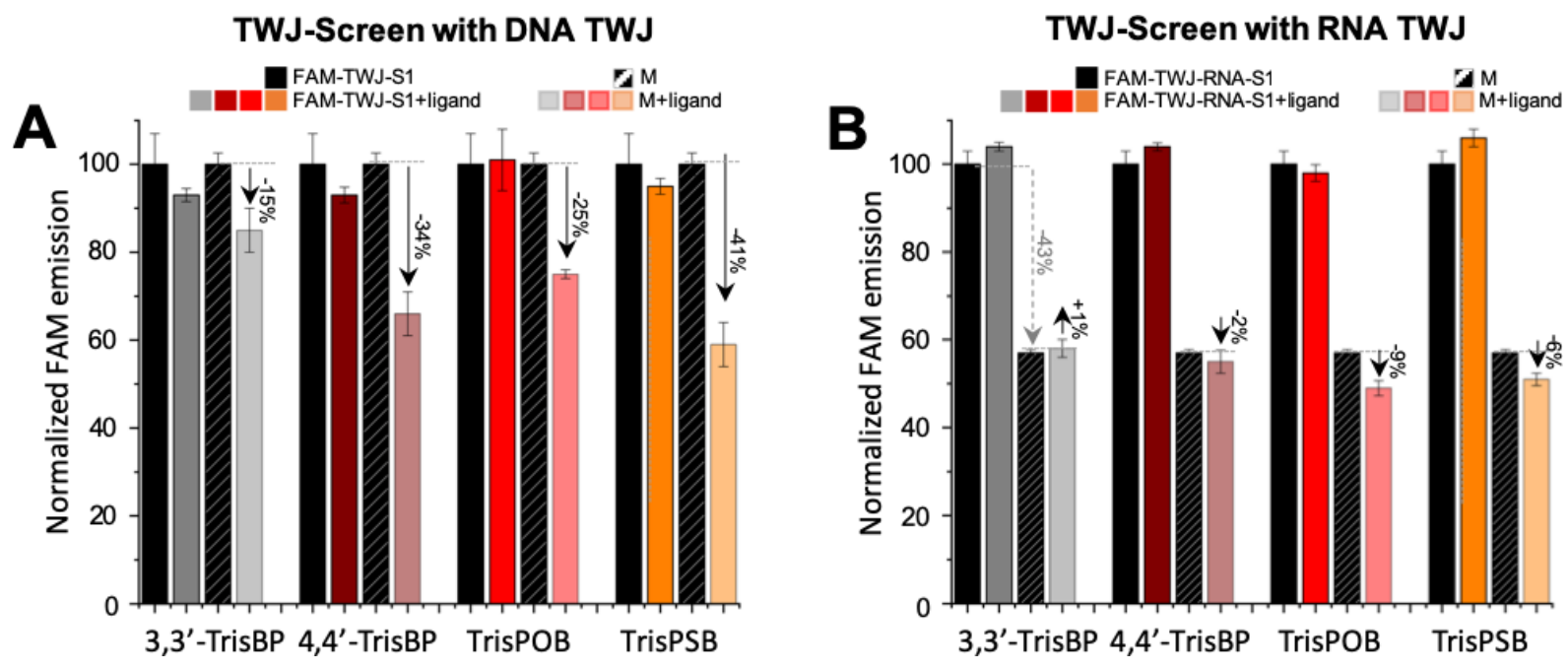

Figure S4. TWJ-Screen results of experiments performed FAM-TWJ- $\mathrm{S}_{1}, \mathrm{TWJ}_{-} \mathrm{S}_{2}$ and TWJ-S - TAMRA $(0.2 \mu \mathrm{M})$ (A) or with FAM-TWJ-RNA-S ${ }_{1}$, TWJ-RNA-S ${ }_{2}$ and TWJ-RNA-S ${ }_{3}$-TAMRA $(0.2 \mu \mathrm{M})$ (B) in presence of 3,3'-TrisBP, 4,4'TrisBP, TrisPOB and TrisPSB $\left(1 \mu \mathrm{M}, 37^{\circ} \mathrm{C}, 1 \mathrm{~h}\right)$. 
This test appears not ideally suited to the study of RNA TWJ given that the normalized fluorescence intensity (NFI) of the mixture $\mathrm{M}$ is strongly decreased as compared to that of FAM-TWJ-RNA-S1 (-43\%, Figure S4), highlighting the propensity of the three RNA strands to fold into a TWJ quite readily. The comparison of the NFI of $M$ with that of [M + ligand] shows that the azacryptands marginally promote further RNA TWJ folding, with $\mathrm{NFI}_{\mathrm{M} \text {-[M+ligand] }}$ values between +1 and $-9 \%$ as compared to $\mathrm{NFI}_{\mathrm{M}}$ (versus $\mathrm{NFI}_{\mathrm{M}-[\mathrm{M}+\text { ligand] }}$ values between -15 and $-41 \%$ as compared to $\mathrm{NFI}_{\mathrm{M}}$ for DNA TWJ).

\section{FRET-melting with RNA TWJ}

The FRET-melting assay was initially performed with the doubly labeled DNA TWJ FAM-

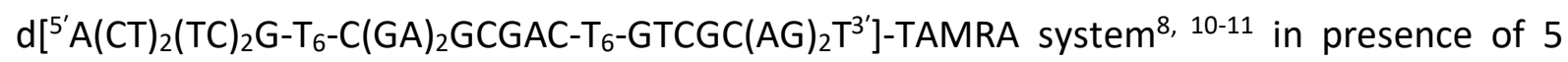
mol. equiv. $(1.0 \mu \mathrm{M})$ of ligands and heated from 25 to $90{ }^{\circ} \mathrm{C}\left(1{ }^{\circ} \mathrm{C} /\right.$ step $)$. We repeated it with the doubly labeled RNA TWJ FAM-r $\left[{ }^{\prime} A(C U)_{2}(U C)_{2} G-U_{6}-C(G A)_{2} G C G A C-U_{6}-G U C G C(A G)_{2} U^{3}\right]-$ TAMRA system in presence of 5 mol. equiv. $(1.0 \mu \mathrm{M})$ of ligands as well. $\Delta \mathrm{T}_{1 / 2}$ values seen in Figure S5 highlight the far weaker stabilization imparted by the ligands to RNA TWJ (with $\Delta \mathrm{T}_{1 / 2}$ values between 1 and $\left.9^{\circ} \mathrm{C}\right)$ as compared to the DNA TWJ $\left(\Delta \mathrm{T}_{1 / 2}\right.$ values between 14 and $\left.20^{\circ} \mathrm{C}\right)$.

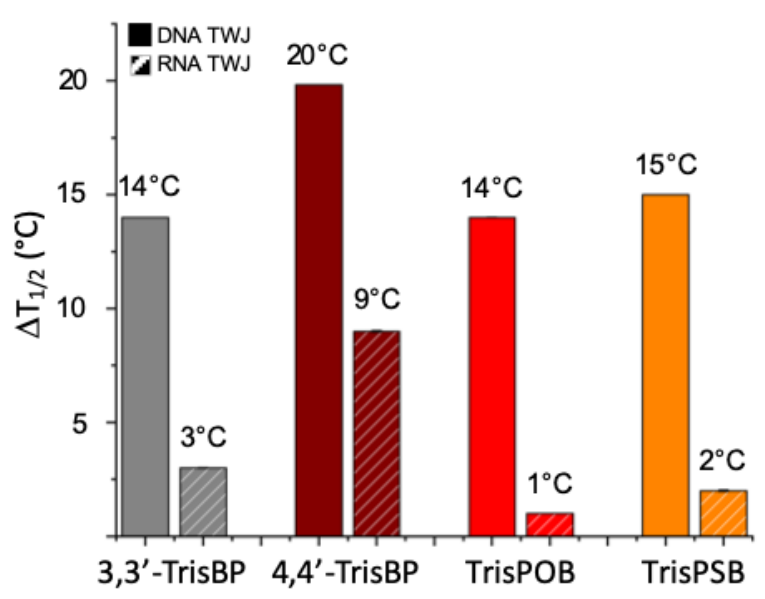

Figure S5. FRET-melting experiment performed with 0.2 $\mu \mathrm{M}$ DNA F-TWJ-T (plain bars) or RNA F-TWJ-T (hatched bars) in presence of $3,3^{\prime}$-TrisBP, $4,4^{\prime}$-TrisBP, TrisPOB and TrisPSB $(1.0 \mu \mathrm{M})$.

\section{ESI-MS experiments with RNA TWJ}

The ESI-MS experiments were initially performed with the DNA TWJ $d\left[{ }^{5} A(C T)_{2}(T C)_{2} G_{-} T_{6}-\right.$ $\left.C(G A)_{2} G_{C G A C}-T_{6}-G T C G C(A G)_{2} T^{3}\right]$ in absence (control) or presence of the azacryptands at 1:1 DNA:ligand ratio. Results seen in Figure S6A demonstrated the very high affinity of the ligand 
for TWJ since only the 1:1 TWJ/ligand complexes were found for 4,4'-TrisBP, TrisPOB and TrisPSB (no free DNA was detectable), while small amounts of unbound DNA were still detectable with 3,3'-TrisBP. The calculation of the apparent equilibrium association constants $(K)$ was therefore unreliable, ${ }^{12}$ except for 3,3'-TrisBP $\left(K=1.9 \times 10^{6} \mathrm{M}^{-1}\right)$, with $\mathrm{K}$ values estimated $>10^{8} \mathrm{M}^{-1}$.
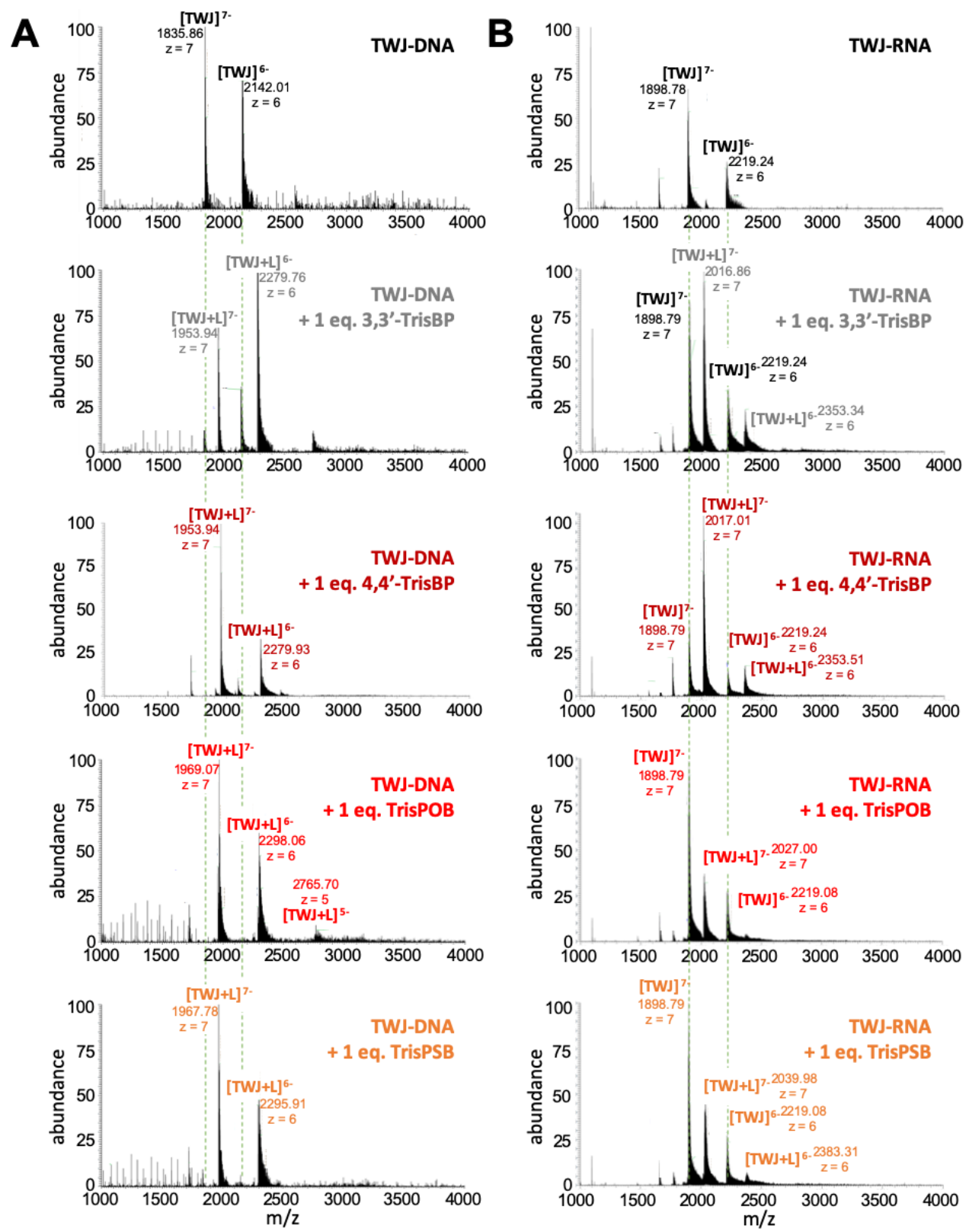

Figure S6. ESI-MS experiment performed with $10 \mu \mathrm{M}$ DNA TWJ (A) or RNA (B) in absence (upper panels) or presence of 3,3'-TrisBP, 4,4'-TrisBP, TrisPOB and TrisPSB (10 $\mu \mathrm{M})$.

Similar experiments were performed with the RNA TWJ r $\left[{ }^{5} A(C U)_{2}(U C)_{2} G-U_{6}-C(G A)_{2} G C G A C-U_{6}-\right.$ GUCGC(AG) ${ }_{2} \mathrm{U}^{3^{\prime}}$ ] (Figure S6B): the lower affinity of the ligands for the RNA TWJ is illustrated by 
the significant amounts of free DNA found in every condition, making the calculation of the $K$ values $\left(K=[D N A: l i g a n d] /\left(\left[D N A_{\text {free }}\right][\right.\right.$ ligand free $\left.\left.]\right)\right)$ possible, with $K=2.0 \times 10^{5}, 7.3 \times 10^{5}, 1.4 \times 10^{5}$ and $7.8 \times 10^{4} \mathrm{M}^{-1}$ for $3,3^{\prime}$-TrisBP, 4,4'-TrisBP, TrisPOB and TrisPSB, respectively, that is, $>2$ orders of magnitude lower than those obtained with DNA TWJ.

\section{Bibliography}

1. De Cian, A.; Guittat, L.; Kaiser, M.; Sacca, B.; Amrane, S.; Bourdoncle, A.; Alberti, P.; Teulade-Fichou, M.-P.; Lacroix, L.; Mergny, J.-L., Fluorescence-based melting assays for studying quadruplex ligands. Methods 2007, 42 (2), 183-195.

2. Haudecoeur, R.; Stefan, L.; Monchaud, D., Multitasking Water-Soluble Synthetic GQuartets: From Preferential RNA-Quadruplex Interaction to Biocatalytic Activity. Chem. Eur. J. 2013, 19 (38), 12739-12747.

3. Di Antonio, M.; Biffi, G.; Mariani, A.; Raiber, E.-A.; Rodriguez, R.; Balasubramanian, S., Selective RNA Versus DNA G-Quadruplex Targeting by In Situ Click Chemistry. Angew. Chem. Int. Ed. 2012, 51 (44), 11073-11078.

4. Mergny, J. L.; Phan, A. T.; Lacroix, L., Following G-quartet formation by UV-spectroscopy. FEBS Lett. 1998, 435 (1), 74-78.

5. Palacky, J.; Vorlickova, M.; Kejnovska, I.; Mojzes, P., Polymorphism of human telomeric quadruplex structure controlled by DNA concentration: a Raman study. Nucleic Acids Res. 2013, 41 (2), 1005-1016.

6. Kypr, J.; Kejnovska, I.; Renciuk, D.; Vorlickova, M., Circular dichroism and conformational polymorphism of DNA. Nucleic Acids Res. 2009, 37 (6), 1713-1725.

7. Laguerre, A.; Chang, Y.; Pirrotta, M.; Desbois, N.; Gros, C. P.; Lesniewska, E.; Monchaud, D., Surface-promoted aggregation of amphiphilic quadruplex ligands drives their selectivity for alternative DNA structures. Org. Biomol. Chem. 2015, 13 (25), 7034-7039.

8. Novotna, J.; Laguerre, A.; Granzhan, A.; Pirrotta, M.; Teulade-Fichou, M.-P.; Monchaud, D., Cationic azacryptands as selective three-way DNA junction binding agents. Org. Biomol. Chem. 2015, 13 (1), 215-222.

9. Guyon, L.; Pirrotta, M.; Duskova, K.; Granzhan, A.; Teulade-Fichou, M.-P.; Monchaud, D., TWJ-Screen: an isothermal screening assay to assess ligand/DNA junction interactions in vitro. Nucleic Acids Res. 2018, 46 (3), e16.

10. Stefan, L.; Bertrand, B.; Richard, P.; Le Gendre, P.; Denat, F.; Picquet, M.; Monchaud, D., Assessing the Differential Affinity of Small Molecules for Noncanonical DNA Structures. ChemBioChem 2012, 13 (13), 1905-1912.

11. Duskova, K.; Lamarche, J.; Amor, S.; Caron, C.; Queyriaux, N.; Gaschard, M.; Penouilh, M.-J.; de Robillard, G.; Delmas, D.; Devillers, C. H.; Granzhan, A.; Teulade-Fichou, M.-P.; Chavarot-Kerlidou, M.; Therrien, B.; Britton, S.; Monchaud, D., Identification of ThreeWay DNA Junction Ligands through Screening of Chemical Libraries and Validation by Complementary in Vitro Assays. J. Med. Chem. 2019, 62 (9), 4456-4466.

12. Rosu, F.; Gabelica, V.; Houssier, C.; De Pauw, E., Determination of affinity, stoichiometry and sequence selectivity of minor groove binder complexes with double-stranded oligodeoxynucleotides by electrospray ionization mass spectrometry. Nucleic Acids Res. 2002, 30 (16), e82-e82. 